\title{
Fate of antibiotic resistance genes in two Arctic tundra wetlands impacted by municipal wastewater
}

Hayward, Jennifer L.; Jackson, Amy J.; Yost, Christopher K.; Hansen, Lisbeth Truelstrup; Jamieson, Rob C.

Published in:

Science of the Total Environment

Link to article, DOI:

10.1016/j.scitotenv.2018.06.083

Publication date:

2018

Document Version

Peer reviewed version

Link back to DTU Orbit

Citation $(A P A)$ :

Hayward, J. L., Jackson, A. J., Yost, C. K., Hansen, L. T., \& Jamieson, R. C. (2018). Fate of antibiotic resistance genes in two Arctic tundra wetlands impacted by municipal wastewater. Science of the Total Environment, 642, 1415-1428. https://doi.org/10.1016/j.scitotenv.2018.06.083

\section{General rights}

Copyright and moral rights for the publications made accessible in the public portal are retained by the authors and/or other copyright owners and it is a condition of accessing publications that users recognise and abide by the legal requirements associated with these rights.

- Users may download and print one copy of any publication from the public portal for the purpose of private study or research.

- You may not further distribute the material or use it for any profit-making activity or commercial gain

- You may freely distribute the URL identifying the publication in the public portal 
1 Fate of antibiotic resistance genes in two Arctic tundra wetlands impacted by municipal

2 wastewater.

3 Jennifer L. Hayward ${ }^{\mathrm{a}}$, Amy J. Jackson ${ }^{\mathrm{a}}$, Christopher K. Yost ${ }^{\mathrm{b}}$, Lisbeth Truelstrup Hansen ${ }^{\mathrm{c}}$, Rob

4 C. Jamieson ${ }^{\mathrm{a}, *}$

$5 \quad{ }^{\mathrm{a}}$ Centre for Water Resources Studies, Department of Civil \& Resource Engineering,

6 Dalhousie University, 1360 Barrington St., Halifax, Nova Scotia, Canada, B3H 4R2

7 bepartment of Biology, University of Regina, 3737 Wascana Parkway, Regina, Saskatchewan,

8 Canada, S4S 0A2

$9{ }^{c}$ National Food Institute, Technical University of Denmark, DK-2800 Kongens Lyngby,

10 Denmark.

11 (jenny.hayward@dal.ca; amy.j@dal.ca; chris.yost@uregina.ca; lisbeth.truelstrup.hansen@dal.ca;

12 jamiesrc@dal.ca)

$13 *$ Corresponding author: Rob Jamieson, Dalhousie University, jamiesrc@dal.ca

\section{Highlights}

- Antibiotic resistance genes (ARGs) were assessed in two tundra wastewater wetlands.

16 - Hydrology of the wetlands was an important factor for ARG concentrations.

17 - Spring runoff increased ARG concentrations in water with high flows.

- Un-impacted reference wetlands were assessed for ARGs.

- Preliminary first order rate constants were ARG specific. 


\section{Abstract}

In the Canadian Arctic, it is common practice to discharge municipal wastewater into tundra wetlands. Antibiotic resistant bacteria and the antibiotic resistance genes (ARGs) they contain can be present in municipal wastewater and there is a scarcity of knowledge on ARGs in wastewater in Arctic environments. This study was initiated on the fate of ARGs in tundra wetland ecosystems impacted by anthropogenic wastewater sources in Arctic communities. In the summer season of 2016, two wetlands were studied in the Inuit communities of Sanikiluaq and Naujaat in Nunavut, Canada. Genomic DNA was extracted from both soil and water during the spring freshet and late summer in the wetlands, and a suite of nine clinically relevant ARGs (sul1, sul2, mecA, vanA, qnrS, ermB, tetO, bla $a_{T E M}, b_{C T X-M}$ ), and an integron gene (int1) were analyzed using quantitative polymerase chain reaction (qPCR). Hydrological and water quality measurements were conducted in conjunction with the microbiological sampling. Gene targets were consistently present in the wastewater, and throughout both wetlands, except for vanA and mecA. Concentrations of ARGs were greater during the spring freshet, due to short hydraulic retention times $(<2$ days), which coincided with decreased treatment performance. The natural resistome in un-impacted wetlands had above detection limit concentrations of int1, sul1, sul2, bla $_{\text {CTX-M }}$ in water in Naujaat, and sul1, qnrS and tetO in soil in Sanikiluaq. First-order rate constants were widely variable and specific to the gene target. ARGs were present in concentrations elevated above baseline reference sites in tundra wetlands influenced by municipal wastewater, and hydrological conditions had a large impact on their spatial 41 distribution and levels.

Keywords: ARG, tundra wetland hydrology, qPCR, cold climate, Arctic, antimicrobial resistance 


\section{Introduction}

The development of antimicrobial resistance (AMR) has become a prevalent global public health issue (Davies \& Davies, 2010). Antibiotics are present in municipal wastewater, originating from partially metabolized medications used by humans and disposal of un-used antibiotics (Nagulapally et al., 2009). Antibiotic resistant bacteria (ARB), and associated antibiotic resistance genes (ARGs), can accumulate and persist in human and agricultural wastes and then be applied or released into terrestrial and aquatic environments (Ashbolt, 2013; Czekalski et al., 2012). These AMR contaminants pose human health risks as previously curable infections are now becoming resistant to conventional antibiotics (Ashbolt, 2013; Laxminarayan et al., 2013). Research has begun to demonstrate that some environments can behave as reactors for ARB proliferation, such as wastewater treatment plants (Czekalski et al., 2012; Rizzo et al., 2013). Soil and water environments can function as environmental reservoirs for ARGs (Martinez, 2008; Taylor et al., 2011), and it has been demonstrated that some ARGs are part of the ancient soil microbiome (D'Costa et al., 2011). Potential for conference of ARGs between environmental soil bacteria and human pathogens has been suggested by Forsberg et al. (2012). In some regions the baseline environmental levels of ARGs have been observed to be increasing under anthropogenic pressures (Knapp et al., 2009). There is concern that increasing anthropogenic use of antibiotics is contributing to selective pressure and increased risk of horizontal gene transfer to human pathogens (Qiu et al., 2012). Characterization of the persistence of ARGs is crucial for human health risk assessment (HHRA) (Bouki et al., 2013).

Specifically, quantification of the clinically relevant AMR bacteria within the potential exposure sites to humans and animal vectors within the environment is required to inform quantitative microbial risk assessment (QMRA), and this type of data has been reported to be limited 
67 (Huijbers et al., 2015). One knowledge gap in the HHRA process includes quantification of ARGs and AMR bacteria hot spots in the environmental dimension, specifically soil and aquatic systems (Ashbolt et al., 2013).

The extreme climate and remoteness of the expansive region of the Canadian Arctic restricts wastewater management options, increases costs and often leads to difficulties with operation and maintenance of wastewater infrastructure (Johnson et al., 2014; Yates et al., 2012). The majority of communities in Canada's Far North use centralized methods of wastewater management with passive treatment systems comprised of lagoons (Johnson, 2008); also referred to as wastewater stabilization ponds (WSPs). In many communities, these systems are not engineered, and consist of a natural depression in the landscape. Due to permafrost, most communities have trucked water distribution systems for drinking and wastewater with storage on an individual household level (Daley et al., 2014). Engineered lagoons operate as one-year detention controlled discharge storage ponds which remain frozen most of the year. Typically, discharge occurs at the end of a three-month "treatment season" spanning from late-June to early-September (Ragush et al., 2015). Conversely, non-engineered systems release wastewater in an uncontrolled manner at the start of the spring thaw or freshet, continuing throughout the summer. The lagoons often discharge to tundra wetlands, which are natural features of the landscape where polishing of effluent has been observed prior to discharge into primarily marine receiving water environments (Yates et al., 2012; Hayward et al., 2014; Balch et al., 2018). These wetland areas have been used for wastewater disposal for decades (Balch et al., 2018), and have been termed Wetland Treatment Areas (WTAs). The treatment performance and attenuation of conventional wastewater contaminants within tundra WTAs has been observed to have high 
temperature with increased treatment observed when hydraulic retention times (HRTs) are sufficient to allow treatment (Hayward et al., 2014; Balch et al., 2018). For example, Yates et al. (2012) reported WTAs were effective for wastewater treatment with contaminant removal rates in six WTAs over an Arctic summer which ranged from 47 - 94\% for five-day biochemical oxygen demand $\left(\mathrm{CBOD}_{5}\right), 39$ - 98\% for total suspended solids (TSS), $>99 \%$ for Escherichia coli (E. coli), $84-99 \%$ for un-ionized ammonia $\left(\mathrm{NH}_{3}-\mathrm{N}\right)$, and $80-99 \%$ for total phosphorus (TP).

It has been observed that the removal of human pathogens from some lagoons in the Canadian Arctic may be inadequate (Huang et al., 2017). Due to lack of disinfection, there may be an elevated risk of development of AMR in the microbial communities associated with Arctic wastewater treatment systems (WWTSs), which is exacerbated by low ambient temperatures and low biological diversity in the receiving waters (Gunnarsdóttir et al., 2013). A potential contributing problem in Arctic environments includes the demonstrated potential for longer survival time of some bacteria in cold temperatures (Howell et al., 1996). Although population sizes in the Canadian Arctic are relatively small-with few commercial agriculture and aquaculture industries - there is still cases of higher reported incidence of enteric infection in comparison to southern Canada (Harper et al., 2015) and AMR could be problematic (Gunnarsdóttir et al., 2013). Since WWTSs are located within or near many northern and remote communities, human-environment interactions could pose a risk of exposure to pathogens associated with wastewater via direct contact with the landscape or aquatic environment, or through contact with wildlife vectors (Daley et al., 2015; Pardhan-Ali et al., 2013; Founou et al., 2016; Harper et al, 2011). The possibility for wildlife to act as vectors for spreading of AMR from urban to rural areas in Arctic environments has been demonstrated in Alaskan seagulls carrying antibiotic resistant strains of E. coli (Atterby et al., 2016; Ramey et al., 2017). 
113 However, there have been limited studies conducted specifically on AMR in the Arctic due to the

114 logistical and financial constraints associated with travel to these remote communities. Chaves115 Barquero et al. (2016) conducted a study in Cambridge Bay, Nunavut, Canada to assess the 116 concentrations of pharmaceuticals and ARGs (conferring resistance to tetracycline and 117 sulfonamide) in the effluent from a wastewater lagoon and downstream tundra wetland. They 118 concluded that ARGs were found in the lagoon and wetland system and were largely diluted in 119 the marine receiving waters. Neudorf et al. (2017) studied three WWTSs in Nunavut, Canada 120 including two lagoon systems (Pond Inlet and Clyde River), and one mechanical treatment plant 121 (Iqaluit). Their study demonstrated that ARGs (2 log gene copies per $\mathrm{mL}$ ) were present in the 122 effluent discharged into the receiving environments, which could pose a risk for horizontal gene 123 transfer to pathogens. The actual risk posed to human health by ARGs in Arctic receiving 124 environments is unknown at this point. To address this knowledge gap, Neudorf et al. (2017) 125 stated that further research into ARG prevalence and behaviour in Arctic environments is warranted.

127 It is hypothesized that the ARG concentrations in the WTAs will follow trends observed in 128 previous conventional wastewater quality studies on tundra wetlands which showed 129 improvements in water quality as the treatment season progressed (Yates et al., 2012; Hayward 130 et al., 2014; Balch et al., 2018). In addition, it is hypothesized that the geographic location of the 131 wetlands may contribute to the observed treatment, with higher latitudes having potentially less 132 precipitation leading to decreased dilution, and lower temperatures, which can slow biological 133 treatment. The overall objective of this study was to quantify the levels of nine ARG targets in 134 soil and water within two tundra wetlands impacted by municipal wastewater in the northern 135 territory of Nunavut, Canada. This study specifically examined the: (i) seasonal hydrologic 
variability effects on the spatial distribution and levels of ARGs with the two treatment wetlands,

137 (ii) natural resistome of un-impacted reference wetlands, and (iii) kinetics of ARG removal.

\section{Methodology}

\subsection{Site descriptions}

140 The two study sites were located in Sanikiluaq (56 32’34" N, 079 $13^{\prime} 30^{\prime \prime}$ W) and Naujaat

141 (66 $\left.31^{\prime} 19^{\prime \prime} \mathrm{N}, 086^{\circ} 14^{\prime} 16^{\prime} \mathrm{W}\right)$ in Nunavut, Canada (Figure 1). Sanikiluaq is in the subarctic

142 region of Canada which was selected as a low latitude site with slightly higher precipitation and

143 average summer air temperatures. Naujaat is located close to the boundary of the Arctic Circle

144 and was selected as representative of a higher latitude site with less precipitation and lower 145 average summer air temperatures. The populations are 882 and 1,082 for Sanikiluaq and Naujaat, 146 respectively (Statistics Canada, 2017a \& b). Average air temperatures in Sanikiluaq range from -

$14728^{\circ} \mathrm{C}$ to $-19^{\circ} \mathrm{C}$ in January, and from $6^{\circ} \mathrm{C}$ to $16^{\circ} \mathrm{C}$ in July. Total precipitation averages $671 \mathrm{~mm}$, 148 with $422 \mathrm{~mm}$ as rainfall, and $2,488 \mathrm{~mm}$ as snow (249 $\mathrm{mm}$ Snow Water Equivalent),

149 (Government of Canada, 2016a). In Naujaat, average air temperatures range from $-34^{\circ} \mathrm{C}$ to $15028^{\circ} \mathrm{C}$ in January, and from $4^{\circ} \mathrm{C}$ to $13^{\circ} \mathrm{C}$ in July. Total precipitation averages $339 \mathrm{~mm}$, with 124 $151 \mathrm{~mm}$ as rainfall, and 2,154 $\mathrm{mm}$ as snow (215 $\mathrm{mm}$ Snow Water Equivalent), (Government of 152 Canada, 2016b). 


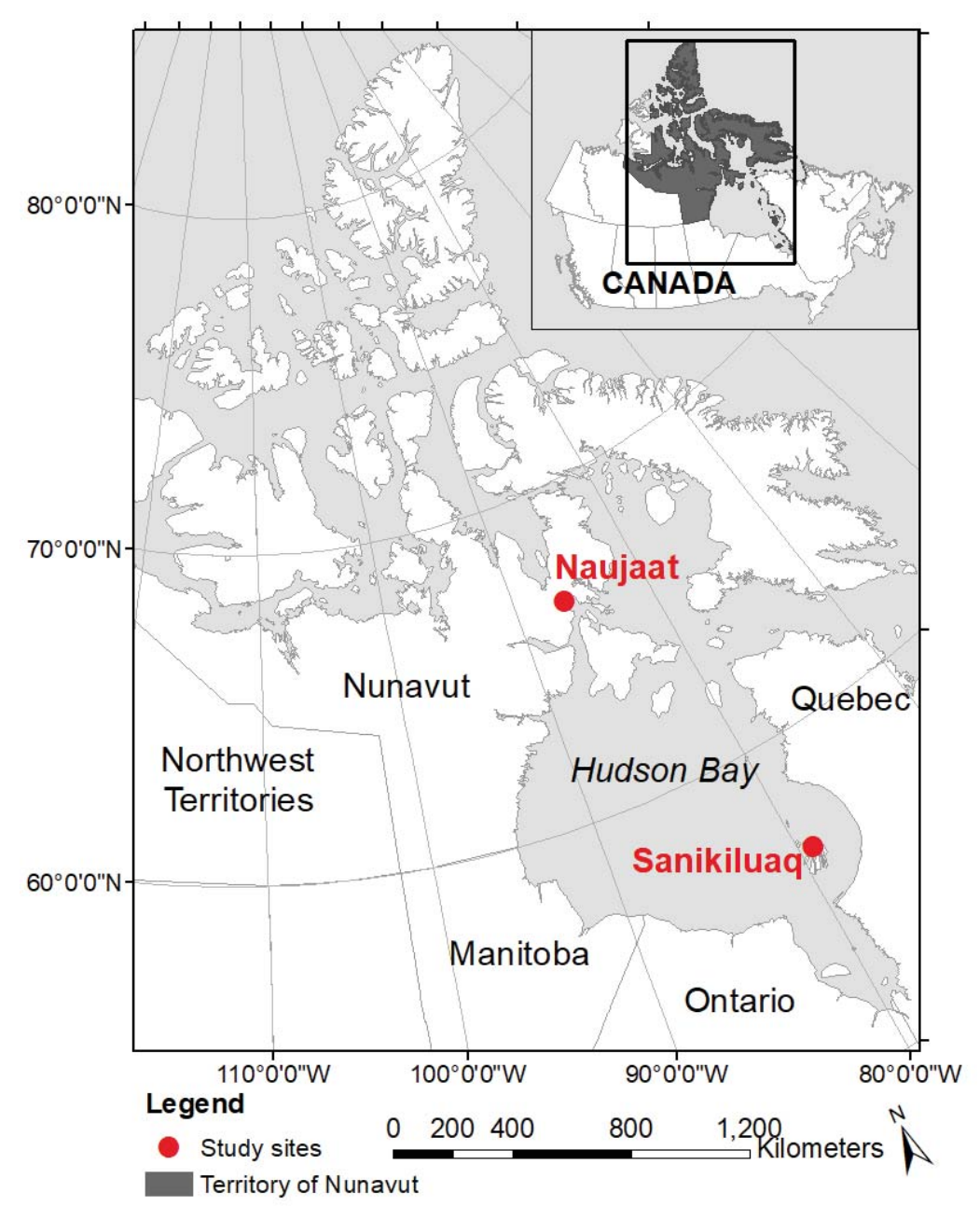

154 Figure 1. Map of study sites in Nunavut, Canada.

155 Both communities use trucked drinking water distribution and waste collection services.

156 Approximately 88 to $100 \mathrm{~m}^{3} /$ day of wastewater is collected in each of the hamlets (Hamlet of

157 Sanikiluaq, 2015; Hamlet of Repulse Bay, 2015). In each of the communities, wastewater is

158 deposited into lagoons, which consist of natural depressions in the landscape. In Sanikiluaq one

159 side of the lagoon has an engineered berm to retain the wastewater. Both WTAs remain frozen

160 throughout the winter months with freeze-up occurring in early to late-September and thaw

161 occurring in late-May in Sanikiluaq and mid-June in Naujaat. Permafrost was not encountered at 
depths of up to $1.5 \mathrm{~m}$ in Sanikiluaq, and the depth of the active layer in Naujaat was generally greater than $0.3 \mathrm{~m}$ in the wetland. Effluent from the lagoons flows by gravity throughout the

164 treatment season into the down-gradient WTAs as shown in Figures 2 and 3. The areas and 165 lengths of the study wetlands are approximately: 3.4 ha and $1 \mathrm{~km}$ (Sanikiluaq); and 3.7 ha and $1661.2 \mathrm{~km}$ (Naujaat). The vegetation in the study wetlands are characterized by various willows, 167 sedges, fireweed, mosses, and grasses; the upland areas were characterized by berries, white 168 heather, lichens, grasses, and mountain avens (the latter only in Naujaat). The watershed areas 169 contributing external hydrologic inputs into the wetlands were 170 ha and 96 ha, for Sanikiluaq 170 and Naujaat, respectively (Figures 2 and 3). Ultimately, the wetlands discharge effluent into 171 marine receiving environments. Data collection was conducted from May $20^{\text {th }}-31^{\text {st }}$ and 172 September $1^{\text {st }}-9^{\text {th }}, 2016$ in Sanikiluaq, and from June $10^{\text {th }}-21^{\text {st }}$ and August $24^{\text {th }}-31^{\text {st }}, 2016$ in 173 Naujaat. The May and June trips were representative of the spring period, when snow and ice 174 melt is occurring; while the August and September trips were representative of the summer 175 period, which is characteristically more arid in many tundra wetlands (Hayward et al., 2014). 


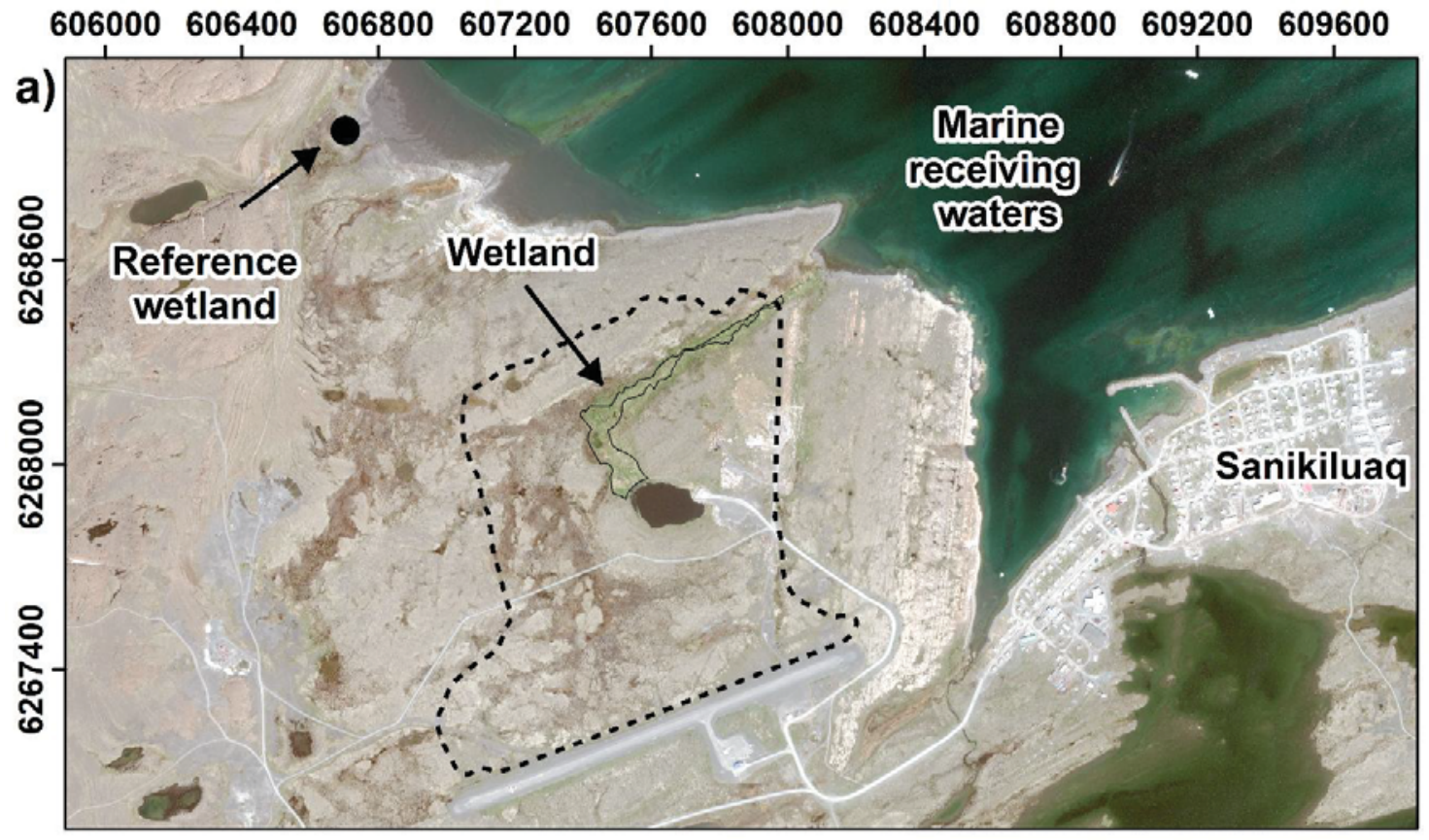

b)

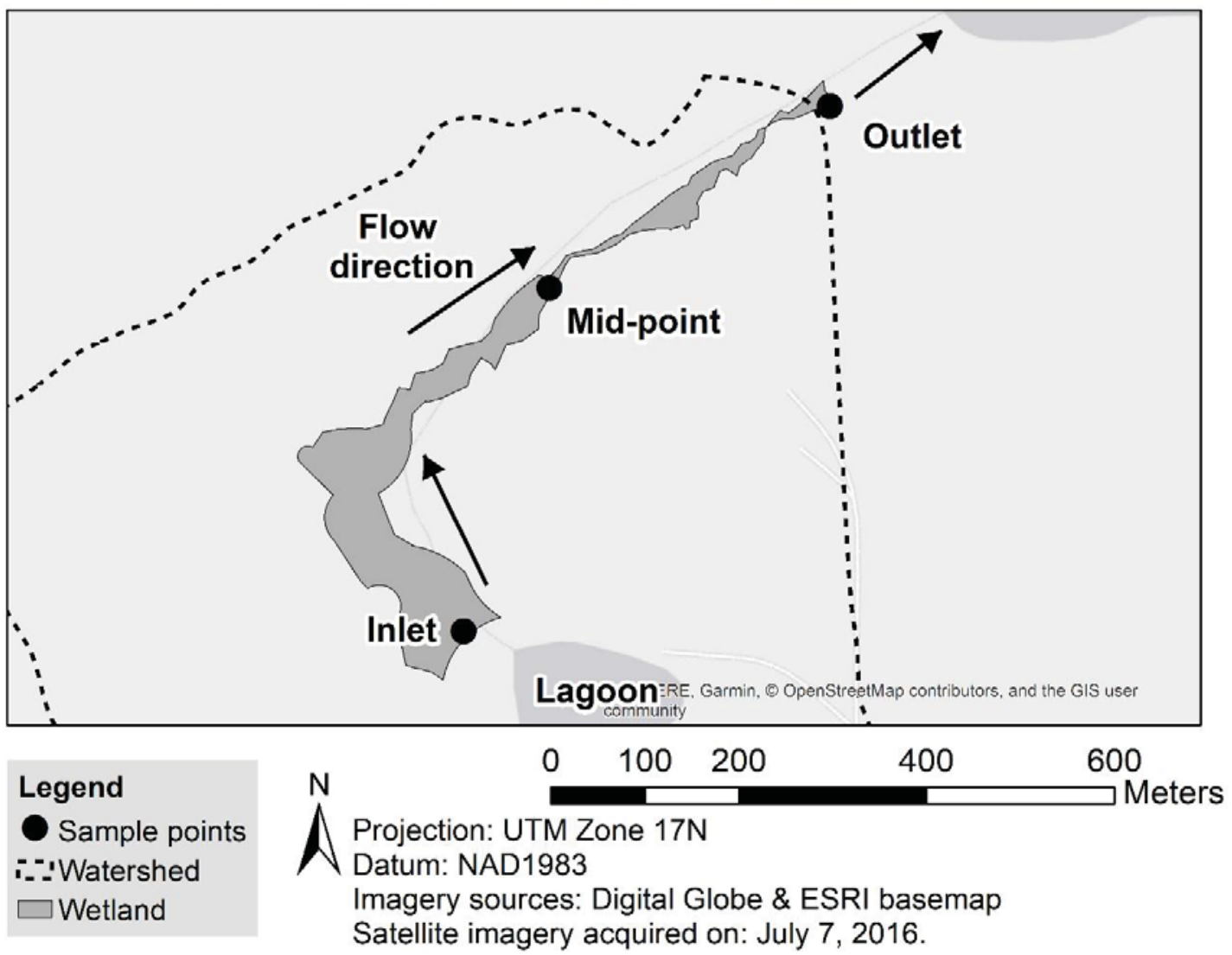


177 Figure 2. a) Satellite image overview of Sanikiluaq and the WWTS showing the watershed 178 boundary, and b) grayscale plan view map of the WTA showing the location of the sample 179 points.

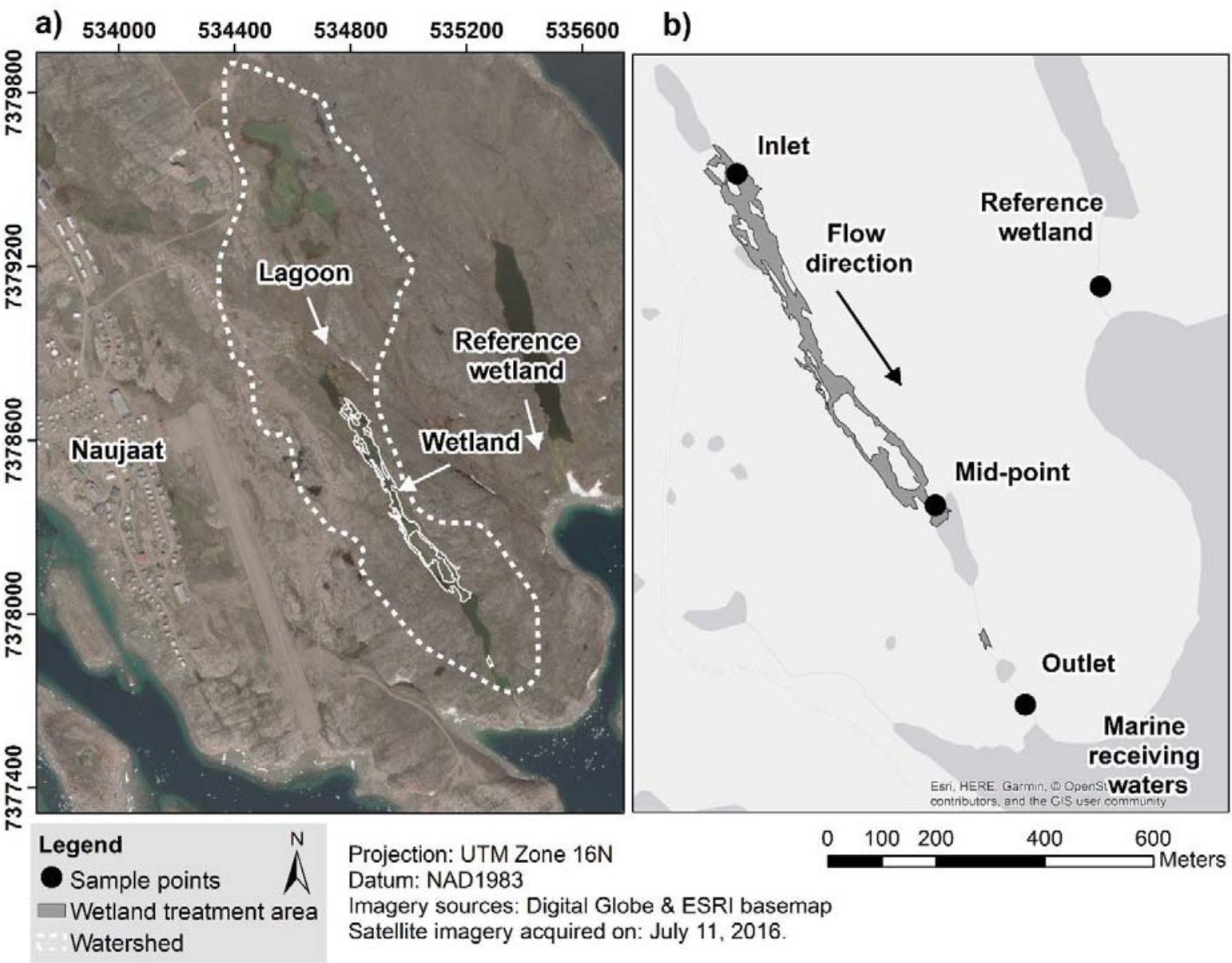

181 Figure 3. a) Satellite image overview of Naujaat and the WWTS showing the watershed

182 boundary, and b) grayscale plan view map of the WTA showing the location of the sample

183 points.

185 A reference wetland with similar physical attributes to the WTAs was selected at each study site.

186 This allowed for comparison of ARG levels and general water quality between the study 
wetlands and the natural tundra landscape. The locations of the reference wetlands are shown in

188 Figures 2 and 3. Both reference wetlands were $70 \mathrm{~m}-90 \mathrm{~m}$ upgradient of the intertidal zone and not under the influence of tidal action. Water quality and soil samples were collected at two locations in flowing water channels separated by $75 \mathrm{~m}$ in Sanikiluaq and $15 \mathrm{~m}$ in Naujaat within each of the reference wetlands. The sample sites were selected to capture running surface water flow from permanent drainage channels in the reference wetlands. The reference wetland in Sanikiluaq was sampled for surface water twice during each site visit. Whereas, in the reference wetland in Naujaat was sampled for surface water twice in June and only once in August. Therefore, six and five reference surface water samples were collected over the treatment season in Sanikiluaq and Naujaat respectively.

\subsection{Hydraulic and hydrology characterization}

Instantaneous discharge was measured within the study wetlands at the inlets, mid-points, and outlets with a 625DF2N digital pygmy meter (Gurley Precision Instruments, Troy, New York, United States). The velocity-area method was used to determine the instantaneous discharge according to Dingman (2002). Stage-discharge relationships were developed at the outlets of the wetlands and combined with continuous water level measurements collected with HOBO U20 Water Level loggers (Onset Computer Corporation, Bourne, Massachusetts, United States) to continuously measure flow. Discrete measurements of flow were conducted at the inlets. Rhodamine WT (RWT) fluorescent dye with a standard concentration of $200 \mathrm{~g} / \mathrm{L}$ RWT was used to conduct tracer tests within the wetlands during each site visit to aid with wetland delineation and to characterize the hydraulic parameters of the wetlands including hydraulic retention times (HRTs) and mixing and dispersion behaviour. The tracer concentration response curves were processed according to the procedure detailed in Hayward et al. (2014). The watersheds of each 
of the wetlands were delineated with ArcGIS ArcMap 10 software (ESRI, Redlands, California,

211 United States). Digital Elevation Models (DEMs) with a spatial resolution of $30 \mathrm{~m}$ were sourced

212 for each site from the Natural Resources Canada online database GeoGratis (Government of

213 Canada, 2017). A real-time kinematic (RTK) topographic survey was conducted in Sanikiluaq

214 due to the requirement for a finer spatial resolution DEM. The hydraulic loading rates were

215 calculated by dividing the minimum, maximum, and average wetland discrete inflows $\left(\mathrm{m}^{3} / \mathrm{d}\right)$

216 over the treatment season by the delineated wetland areas $\left(\mathrm{m}^{2}\right)$ and conversion of units to

217 centimetres per day.

\subsection{Water quality sampling and analysis}

Raw wastewater samples were collected from the pump trucks to characterize untreated wastewater quality parameters and ARG concentrations. Water samples were collected from the inlet, mid-points, and outlet of the wetlands in sterilized 1L plastic sample bottles. Water samples were also collected from two locations in each of the reference wetlands. General water quality indicators (WQIs) of temperature, dissolved oxygen (DO), specific conductance, and $\mathrm{pH}$ were made in situ for each sample collection with a YSI600 handheld water quality sonde (YSI Inc., Yellow Springs, Ohio, United States), which has lower operational limits of $-5^{\circ} \mathrm{C}$. The sonde was calibrated according to manufacturer's specifications prior to each site visit for all 227 parameters and daily for DO. Water samples for standard water quality parameters were stored 228 chilled at $4^{\circ} \mathrm{C}$ and transported by aircraft to be analyzed within hold times at an accredited 229 commercial laboratory.

230 Water samples were analyzed for $\mathrm{CBOD}_{5}$, TSS, volatile suspended solids (VSS), total coliform 231 (TC), E. coli, total nitrogen (TN), total ammonia nitrogen (TAN), $\mathrm{NH}_{3}-\mathrm{N}$, and $\mathrm{TP}$ according to standard methods (APHA, 2012). Quantification of a standard suite of 32 metals was analyzed 
for all water samples with inductively coupled-mass spectrometry (ICP-MS). Water samples collected in June from Naujaat were analyzed at the commercial laboratory Taiga Environmental in Yellowknife, Northwest Territories. Water samples collected from Sanikiluaq in May were analyzed at the commercial laboratory Maxxam Analytics in Montreal, Quebec. All other samples were analyzed at the commercial laboratory Maxxam Analytics in Winnipeg, Manitoba. The trace metals ICP-MS scan from Taiga Environmental Laboratory was conducted according to EPA method 200.8 (USEPA, 1994). The trace metals ICP-MS scan from Maxxam Analytics Laboratory in Montreal was conducted according to method MA.200 -Mét 1.2 (Government of 241 Québec, 2014). The trace metals ICP-MS scan from Maxxam Analytics Laboratory in Winnipeg 242 was conducted according to Method 6020A R1 (USEPA, 1998). A total of two rounds of water 243 samples were collected from the wetlands per each site visit (e.g., spring and summer). Water 244 samples for general water quality and gene target analysis were collected on May $25^{\text {th }}$ and May $24530^{\text {th }}, 2016$, and September $6^{\text {th }}$ and $8^{\text {th }}, 2016$ in Sanikiluaq. Water samples for general water 246 quality and gene target analysis were collected in Naujaat on June $16^{\text {th }}$ and June $21^{\text {st }}$, 2016, and 247 on August $29^{\text {th }}$ and August $31^{\text {st }}, 2016$ (except reference samples). A total of $1 \mathrm{~L}$ of raw 248 wastewater sample was collected to facilitate the general water quality and gene target analysis 249 per each pump truck sampled. In Sanikiluaq, discrete samples were collected from one truck on 250 May $25^{\text {th }}$, two separate trucks on May $30^{\text {th }}$, and three separate trucks on September $9^{\text {th }}, 2016$. In 251 Naujaat, discrete samples were collected from three separate trucks on June $16^{\text {th }}, 2016$ and three 252 separate trucks on August $31^{\text {st }}, 2016$.

\subsection{Sampling and analysis of soil and water for gene targets}

254 Soil samples were collected from the inlet, mid-point, and outlet of each wetland and at three 255 locations within each of the reference wetlands. Soil samples were only collected once at each 
site near the end of summer due to logistical constraints. Soil samples were collected on 257 September $8^{\text {th }}, 2016$ and August $29^{\text {th }}, 2016$, in Sanikiluaq and Naujaat, respectively. Each soil 258 sample consisted of a composite sample of three sub-samples from each sample collection point. 259 The soil samples were collected by cutting soil with a sterilized knife from the top $0-10 \mathrm{~cm}$ of 260 the bottom substrate and banks of the flow paths of effluent within the study wetlands and 261 reference wetlands. Soil samples were collected directly (either submerged or partially) in the 262 flow paths of the effluent in the WTAs. The soil samples were kept chilled at $4{ }^{\circ} \mathrm{C}$ following 263 collection.

264 Approximately $30-500 \mathrm{~mL}$ of each water sample was filtered through a $0.45 \mu \mathrm{m}$ pore size filter 265 using a Millipore Vacuum Manifold and Microfil Filtration funnels (Millipore, Inc., Bedford, 266 Massachusetts, United States). After filtration, the filter membrane was placed in a $15 \mathrm{~mL}$ falcon 267 tube with $1 \mathrm{~mL}$ of sterilized water to prevent dry out and immediately frozen. The soil (stored at $2684^{\circ} \mathrm{C}$ ) and filters (stored frozen) were transported by aircraft to Dalhousie University in Halifax, 269 Nova Scotia, Canada.

MoBio Powersoil DNA Extraction Kits (VWR International, Ville Mont-Royal, Québec,

271 Canada) were used to extract the genomic DNA from the bacteria within the soil and water 272 samples. ARG target copy numbers were detected using quantitative real-time PCR (qPCR). This 273 study was limited to only nine of the following gene targets which were quantified within the 274 water and soil samples for this study: class I integrase gene (int1), sulfonamide resistance genes 275 (sul1 and sul2), methicillin resistance gene ( 276 fluoroquinolone resistance gene $(q n r S)$, macrolide-lincosamide-streptogramin type B resistance 277 gene (ermB), tetracycline resistance gene (tetO), and class A $\beta$-lactamase genes (bla $a_{T E M}$ and 278 $\left.b l a_{C T X-M}\right)$. The int1 gene was analyzed because it is a genetic indicator of anthropogenic pollution 
and is commonly associated with genes which confer resistance to antibiotics (Gillings et al., 2015). A limitation to this study is that the antibiotic concentrations within the wastewater were not quantified. According to the Canadian AMR surveillance system report, commonly prescribed antibiotics in the northern territories include amoxicillin, azithromycin, ciprofloxacin, doxycycline, and sulfamethoxazole (Government of Canada, 2016c). Of these prescribed antibiotics, the following genes can confer resistance: bla $a_{T E M}, b a_{C T X-M}$ and mecA (amoxicillin); ermB (azithromycin); qnrS (ciprofloxacin); tet (doxycycline); and sul1 and sul2 286 (sulfamethoxazole) respectively (McConnell, 2017). The rationale for the nine gene target panel 287 was partly to characterize the genes that confer resistance to the commonly clinically prescribed 288 antibiotics as identified in Government of Canada (2016c). This suite of gene targets was also 289 selected in attempt to characterize genes which confer resistance to a range of antibiotic classes 290 which have been previously detected within a municipal wastewater treatment plant by 291 Szczepanowski et al. (2009). It should be noted that the nine gene targets are not an exhaustive nor comprehensive list of the genes which confer resistance to conventional antibiotics and this is a limitation of the study. The gene target suite was quantified using TaqMan qPCR on a Bio294 Rad CFX96 Touch system (Bio-Rad, Herculer, California, United States). The 16S ribosomal 295 ribonucleic acid (rRNA) gene copies, which were determined to enable the calculation of the 296 relative abundance of ARGs in the bacterial community, were quantified using SYBR Green 297 qPCR. A complete description of the qPCR methodologies is provided in Neudorf et al. (2017) 298 and the primer and hydrolysis TaqMan probe sequences and cycling conditions are provided in 299 the supplemental information (Table A.1). The limit of quantification (LOQ) (copies/reaction) 300 for each of the gene targets in the suite were: $i n t 1=14, \operatorname{mec} A=69, \operatorname{van} A=138$, sul1 $=12$, sul2 $=$ $30110, q n r S=112, e r m B=14$, tetO $=70, b l a_{T E M}=243$, and $b l a_{C T X-M}=6$, and 16S rRNA $=67,000$. 
The limit of detection (LOD) was 5 copies/reaction (or 1 copy/mL for $500 \mathrm{~mL}$ sample volumes and 10 copies/mL for $50 \mathrm{~mL}$ sample volumes) determined according to McConnell (2017). The

304 units of measurement for absolute abundance of gene target concentrations were determined in 305 gene copies per $\mathrm{mL}$ of water or gram of sediment and presented as log transformed values.

\subsection{Data analysis}

307 The relative abundance for each gene target, except for 16S rRNA, was calculated by dividing 308 each gene target concentration at each sample location per each sampling event by the 16S rRNA 309 concentration and by log transforming this result, which represented log (gene copies/16S rRNA 310 genes). The relative abundance of the gene targets characterizes the proportion of the ARG target 311 copy concentration in the total bacterial population represented by the 16S rRNA gene. The 312 distribution of gene targets refers to the spread of individual absolute gene target concentrations, except for 16S rRNA, at each sample point within each of the two sites.

\subsection{First-order rate constant determination}

315 The first-order removal rate constants $(k)$ are commonly used parameters in constructed 316 treatment wetland design to describe the rates at which conventional wastewater contaminants 317 are attenuated in wetlands. Numerous applications of this chemical reactor contaminant 318 attenuation theory are summarized in Kadlec and Wallace (2009). Generally, the higher the value

319 of $k$, the faster the rate of removal of that contaminant from the wetland (Hayward, 2013). The 320 first-order rate constants for the gene targets were determined with a modified tanks-in-series 321 (TIS) chemical reactor model parameterized with site-specific data according to the procedure 322 detailed in Hayward and Jamieson (2015). The number of TIS determined from the dye tracer 323 data were used to construct and parameterize the Microsoft Excel spreadsheet models which 324 were used to determine the first-order rate constants. An example spreadsheet calculator template 
used to calculate the first-order rate constants is presented in CWRS (2016). The areal first-order rate constants in units of metres per year $(\mathrm{m} / \mathrm{y})$ were adjusted to $20^{\circ} \mathrm{C}\left(k_{20}\right)$ according to the Arrhenius temperature correction equation and coefficients described in Hayward and Jamieson (2015). The temperature adjustment of $k$ to $20^{\circ} \mathrm{C}$ is standard design practice for first-order rate constants to enable comparison to other treatment wetlands. The temperature correction coefficient of 1.07 was selected based on the assumption of doubling the rate of bacterial loss for a $10^{\circ} \mathrm{C}$ temperature rise (Chapra, 1997; Boutilier et al., 2009). Rate constants were determined only in cases when influent and effluent ARG concentrations from the wetlands were above LOQs. There were multiple model runs per site but solely the minimum $k_{20}$ 's are presented in the results. All $k_{20}$ 's were calculated from log transformed input gene concentrations.

\subsection{Statistical analysis}

A principal components analysis (PCA) was conducted on the entire dataset (both wetlands combined) with the following parameters: int1, mecA, sul1, sul2, tetO, blaTEM, 16S rRNA, $\mathrm{CBOD}_{5}$, TSS, VSS, TC, E. coli, TN, TAN, TP, WQIs, and eleven metals (aluminum (Al), barium $(\mathrm{Ba})$, copper $(\mathrm{Cu})$, iron $(\mathrm{Fe})$, manganese $(\mathrm{Mn})$, strontium $(\mathrm{Sr})$, zinc $(\mathrm{Zn})$, calcium $(\mathrm{Ca})$, magnesium $(\mathrm{Mg})$, potassium $(\mathrm{K})$, and sodium $(\mathrm{Na}))$. The PCA data was log-transformed and analyzed as a correlation matrix in SigmaPlot version 13.0 statistical software. For the PCA, the

342 samples were un-pooled, except raw samples which were pooled for each site over the entire 343 sample period, and the reference samples which were pooled for samples collected during the 344 same season (e.g., spring and summer). Paired student t-tests (two-tailed) were used to assess 345 whether the raw wastewater samples, and effluent and reference samples were significantly 346 different with significance attributed at $\mathrm{P}<0.05$. In all instances, S.D. is an abbreviated form of standard deviation. 


\section{Results and Discussion}

\subsection{Hydraulics and hydrology}

The hydrology of both wetlands was strongly influenced by the seasonal changes in climate. High spring freshet flows occurred in late May to June, as the snow and ice which accumulated over the winter melted, with flows decreasing as the summer progressed into July and August (Figures $4 \mathrm{a}$ and $4 \mathrm{~b}$ ). This finding is consistent with observations of seasonal hydrological changes in the WTA studied by Hayward et al. (2014). The surface flows at the wetland inlet in Sanikiluaq were generally much lower than the flows at the outlet throughout the study period (Figure 4a), with a maximum of $529\left(\mathrm{n}=11\right.$ days discrete) and 4,612 $\mathrm{m}^{3} / \mathrm{d}(\mathrm{n}=133$ days continuous) for influent and effluent, respectively. A subsurface flow (i.e., seepage) area of approximately 1.3 ha was observed just downstream of the inlet, which in some locations had a depth of greater than $1.5 \mathrm{~m}$. The subsurface flow was not quantified but likely accounted for some of the influent flow in Sanikiluaq. Average flow rates for Sanikiluaq over the study period were $196 \mathrm{~m}^{3} / \mathrm{d}\left(\mathrm{n}=11\right.$ days discrete) and $290 \mathrm{~m}^{3} / \mathrm{d}(\mathrm{n}=133$ days continuous) for influent and effluent, respectively. Dilution was observed to range from 392 to $1,111 \%$ during the spring freshet study period in Sanikiluaq, which led to generally better water quality within the wetland

364 and at the outlet. The hydraulic loading rates (HLRs) for Sanikiluaq ranged from 0 to $1.6 \mathrm{~cm} / \mathrm{d}$, 365 with an average of $0.6 \mathrm{~cm} / \mathrm{d}(\mathrm{n}=11$ days discrete). These HLRs are relatively low, and well 366 below typical engineering design criteria for HLRs for free water surface (FWS) wetlands, which 367 range from 2.5 to $12.5 \mathrm{~cm} / \mathrm{d}$ (Water Environment Federation, 2010). However, the HRT in 368 Sanikiluaq during the spring freshet was determined to be 1.4 days from the dye tracer test, 369 which is much shorter than the optimal 14 to 20 days for natural treatment wetlands (Alberta Environment, 2000; Kadlec and Knight, 1996). This may have been indicative of short-circuiting 
of effluent through the wetland. During the summer period, the HRT was longer ( $>7$ days) due to the subsurface flow area in Sanikiluaq and negligible inflow at the inlet. The number of TIS during the spring freshet for the entire wetland was determined to be high for FWS wetlands at 19 TIS; comparatively, for context Kadlec and Wallace (2009) reported a much lower average TIS of close to $4.1 \pm 0.4$ S.D. based on data from 35 constructed FWS wetlands. As the number of TIS approaches infinity, the hydraulic behavior of the wetland approaches plug flow with limited internal mixing (Kadlec and Wallace, 2009), which is not ideal from a treatment perspective. During the September trip, the wetland in Sanikiluaq behaved as a plug-flow reactor. This suggests that during both seasonal periods in Sanikiluaq there was considerable short-circuiting which is not conducive to treatment processes.

The hydrology of the Naujaat wetland system possessed some differences when compared to Sanikiluaq (Figure 4b). During extended periods, the outflow was measured to be lower than the inflow, with minimum flows of $305 \mathrm{~m}^{3} / \mathrm{d}\left(\mathrm{n}=13\right.$ days discrete) and $0 \mathrm{~m}^{3} / \mathrm{d}(\mathrm{n}=79$ days continuous), and average flows of $3,107 \mathrm{~m}^{3} / \mathrm{d}\left(\mathrm{n}=13\right.$ days discrete) and $1,117 \mathrm{~m}^{3} / \mathrm{d}(\mathrm{n}=79$ days) at the inlet and outlet, respectively. This water deficit across the wetland may suggest that the two large ponds downstream of the mid-point in the Naujaat wetland likely acted as detention ponds, and evapotranspiration and seepage may have played a role in removal of surface water from the wetland. In Naujaat, maximum flows of 7,057 $\left(\mathrm{n}=13\right.$ days discrete) and 6,004 $\mathrm{m}^{3} / \mathrm{d}(\mathrm{n}$ $=79$ days continuous) were observed at the inlet and outlet, respectively. The HLRs over the treatment in season in Naujaat ranged from 0.8 to $17.5 \mathrm{~cm} / \mathrm{d}$, with an average of $8.5 \mathrm{~cm} / \mathrm{d}(\mathrm{n}=13$ days discrete), respectively. These HLRs were within the recommended for treatment wetlands for average but not high flow values. The results of the dye tracer tests demonstrated that similar to what was observed in the Sanikiluaq wetland, the HRT measured during the spring freshet was 
394 short (19.5 hours). The HRT in the wetland improved to 8 days later in the summer. The number 395 of TIS determined within the wetland in Naujaat varied over the treatment season, with 17 TIS 396 representative of the entire wetland during the spring, and 13 TIS representative of the system 397 during August. These numbers suggest that there is plug flow-like behavior in the Naujaat 398 wetland as well. 
a) Sanikiluaq

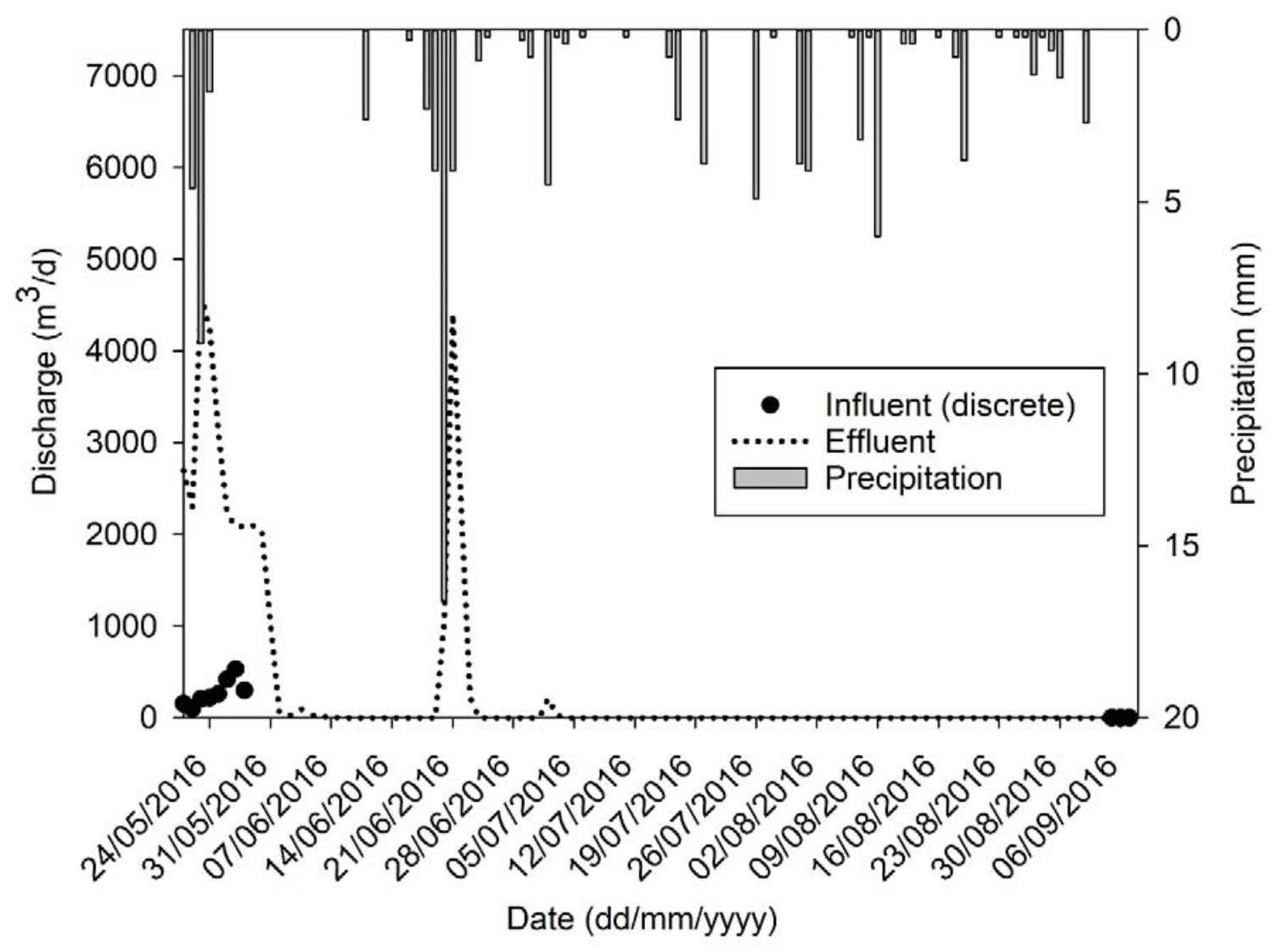




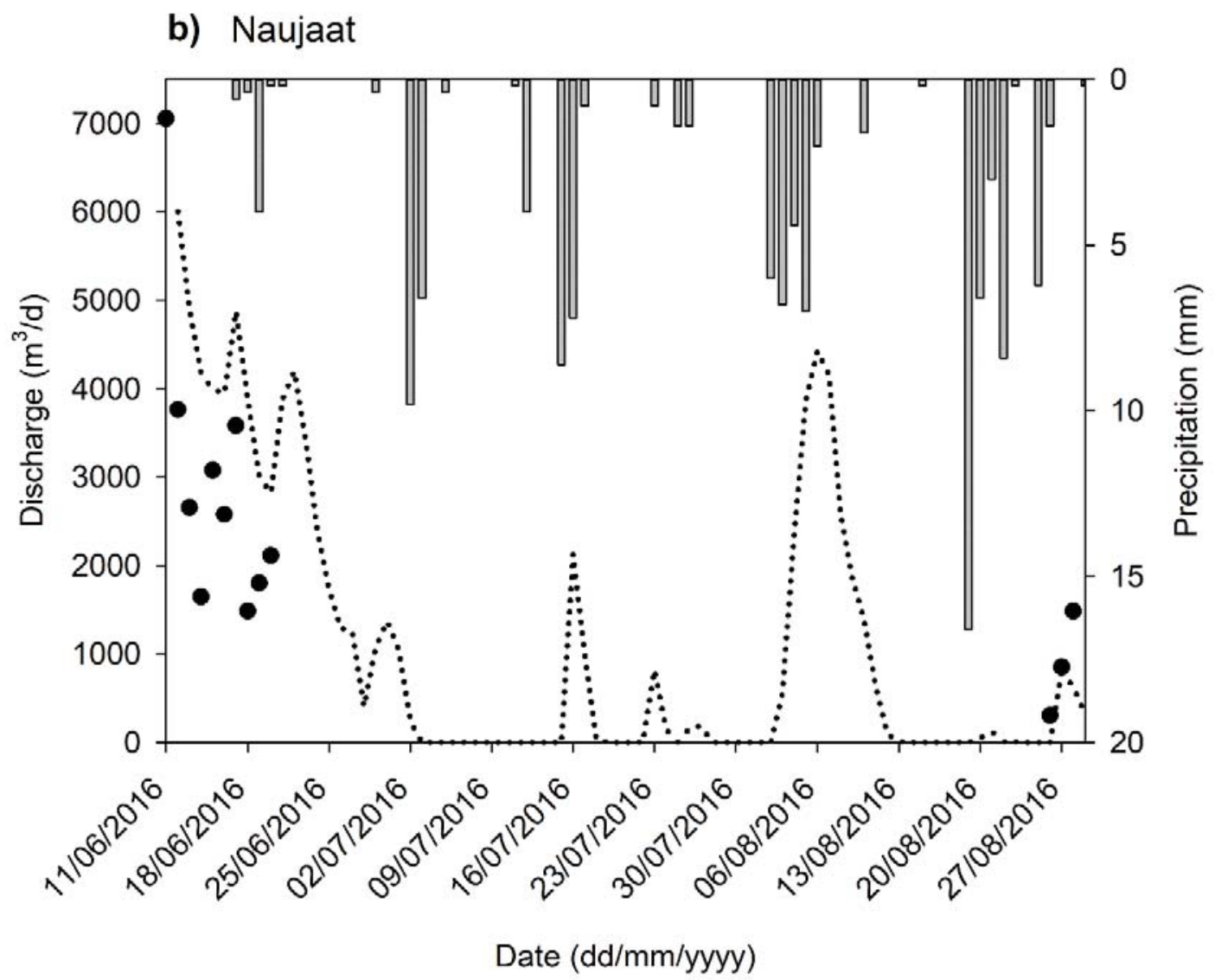

399 Figure 4. Hydrographs from a) the Sanikiluaq wetland; and b) the Naujaat wetland over the

400 treatment season in 2016. The black dots represent the discrete influent measurements collected

401 during the site visits.

\subsection{General Water Quality}

403 The sites both met their respective water licence requirements during the study period at their

404 outlets, except for Naujaat for bacteria in the spring and $\mathrm{pH}$ in the summer (Table 1). At the

405 wetland outlet in Sanikiluaq, average concentration reductions of $56 \%$ for $\mathrm{CBOD}_{5}, 20 \%$ for TSS,

406 and $3.4 \log$ for E. coli were observed during the spring freshet. During the summer, average

407 concentration reductions of $96 \%$ for $\mathrm{CBOD}_{5}, 93 \%$ for TSS, and $3.9 \log$ for E. coli were observed 
408 in the Sanikiluaq wetland. It can be noted that the effluent water quality generally improved as 409 the treatment season progressed. These findings tend to corroborate with observations of 410 seasonality in treatment performance observed in other tundra WTAs by Yates et al. (2012) and 411 Hayward et al. (2014). The average percent reductions from inlet to outlet during the spring in 412 Naujaat were $80 \%$ for $\mathrm{CBOD}_{5}, 48 \%$ for TSS, $0.04 \log$ for E. coli; compared to an average 413 increase of $523 \%$ for $\mathrm{CBOD}_{5}, 21 \%$ reduction for TSS, $5 \log$ reduction for E. coli, and a $60 \%$ 414 increase in $\mathrm{NH}_{3}-\mathrm{N}$ during the summer. The elevated concentrations of organics and solids were 415 likely due to algae accumulation that was noted near the wetland outlet at the end of the 416 treatment season. Comparison between the two sites indicates that Sanikiluaq generally had 417 lower effluent concentrations for contaminants in comparison to Naujaat. In summary, 418 concentrations of most wastewater constituents decreased throughout both wetlands, except at 419 times in Naujaat. Effluent water quality tended to improve over the course of the treatment 420 season. Water samples collected at the outlet of both wetlands possessed elevated levels of 421 organic material, nutrients, and fecal indicator bacteria as compared to reference wetlands (Table $4221)$. 


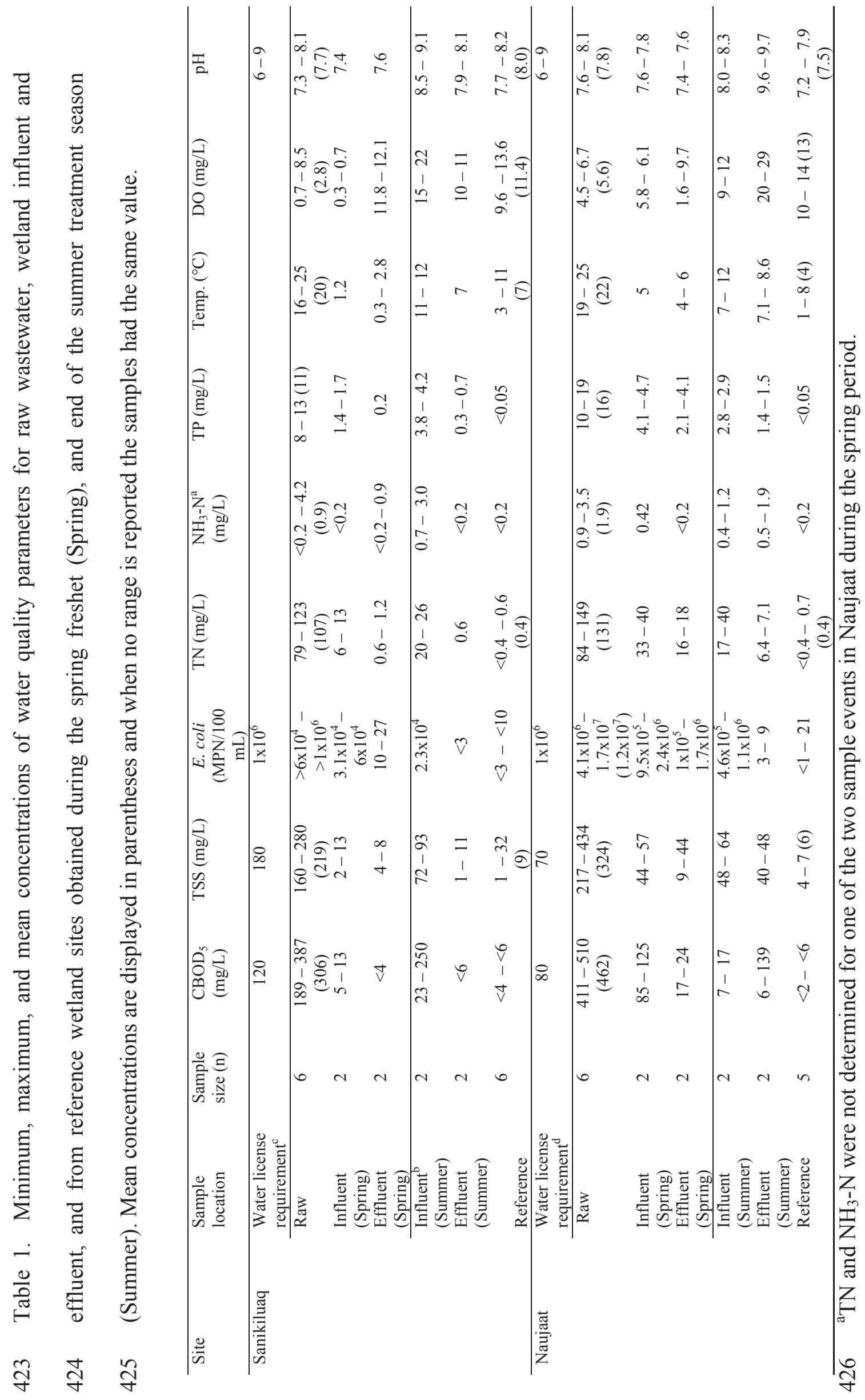




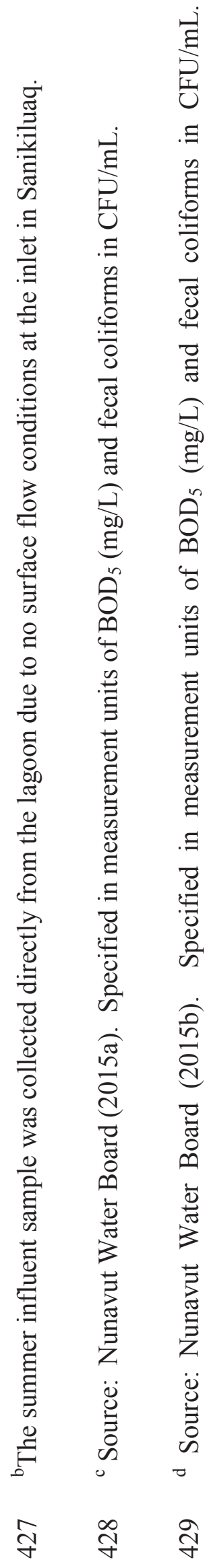


431 The distribution of gene target absolute abundances and 16S rRNA absolute abundance in the 432 raw wastewater and wetlands downstream of the wastewater disposal sites and reference 433 wetlands are summarized in Figure 5. At both sites ARG concentrations were significantly 434 higher in the spring in comparison to summer $(\mathrm{P}<0.05)$ (except at the outlet in Sanikiluaq), and 435 this seasonal variation is linked to the hydrology of the wetlands.

436 This indicates that the spring poses the greatest risk with respect to presence of elevated ARG 437 concentrations in the environment, which corresponds with trends observed from measurements 438 of standard wastewater quality indicators in other WTAs by Hayward et al. (2014) and Yates et 439 al. (2012). The raw wastewater quality between the two sites ( $\mathrm{n}=18$ gene targets) for both 440 sampling seasons were comparable with no significant differences in the distribution of gene 441 target concentrations (paired t-test, $\mathrm{t}=0.74, \mathrm{df}=8 \mathrm{p}=0.48$ ). There was significant difference $442(\mathrm{P}<0.05)$ in the distribution of gene target concentrations between the effluent and reference 443 wetland sample locations during the treatment season in Sanikiluaq (paired t-test, $\mathrm{t}=2.6$, $\mathrm{df}=$ $44417, p=0.02)$. Likewise, in Naujaat there was a significance difference in the distribution of gene 445 target concentrations between effluent and reference wetland sample locations during the 446 treatment season (paired t-test, $\mathrm{t}=6.6, \mathrm{df}=17, \mathrm{p}<0.001$ ). Therefore, the distribution of gene 447 targets at both wetlands did not return to baseline concentrations by the wetland outlets. 


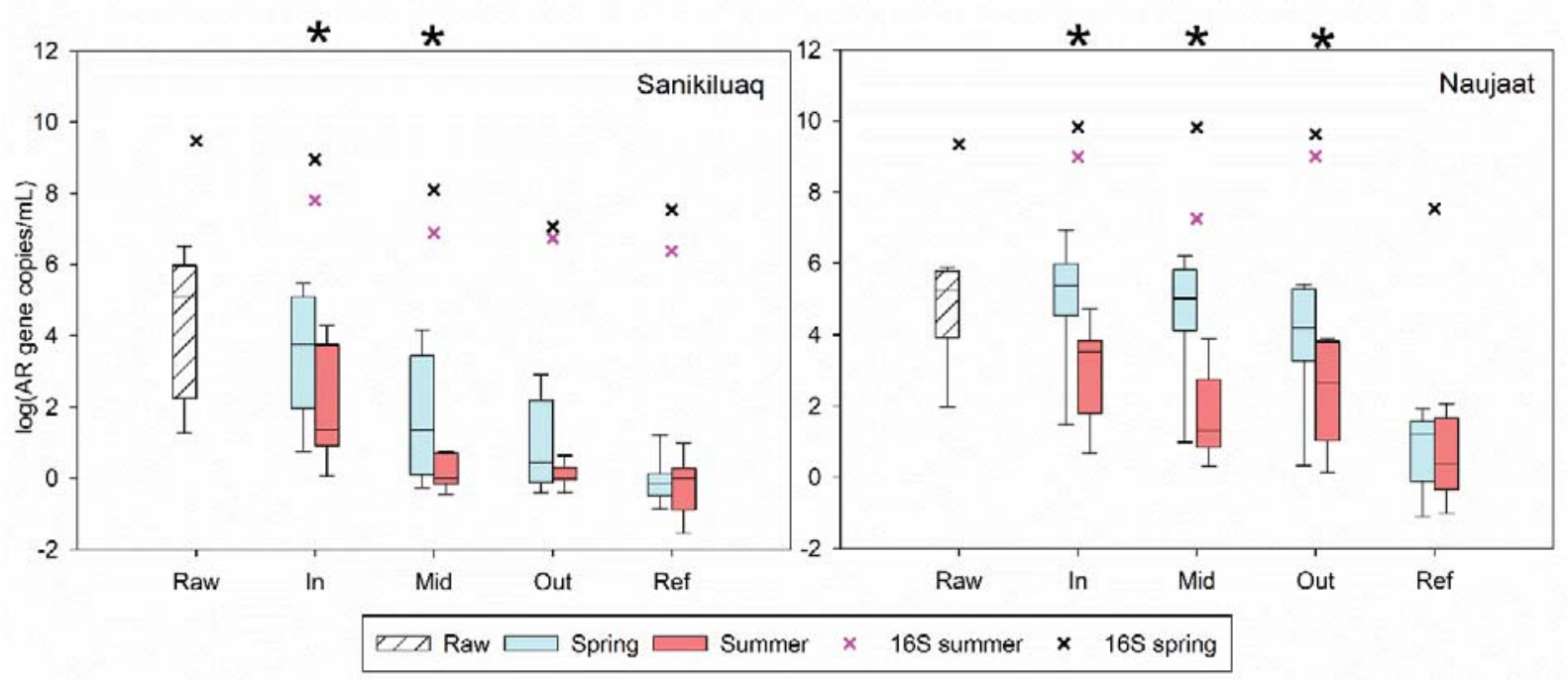

448

449 Figure 5. Distribution of absolute gene target abundances and 16S rRNA gene target absolute

450 abundances at the sample locations in a) Sanikiluaq and, b) Naujaat. The stars on top x-axis are

451 indicative of significant difference of distributions with paired student t-tests at $\mathrm{P}<0.05$. The

452 middle lines represent the mean values, the bottom and top of the boxes represent the $25^{\text {th }}$ and

$45375^{\text {th }}$ percentiles, and the whiskers represent the $10^{\text {th }}$ and $90^{\text {th }}$ percentile of the distribution of gene

454 targets. The raw data distributions were combined over the entire treatment season per site.

\subsection{Absolute abundance in raw wastewater}

456 Absolute abundance of each individual ARG target in the raw wastewater is shown in Figure 6.

457 The gene targets with the highest prevalence in the wetlands were the class I integrase gene int1, 458 sul1, sul2, and qnrS in Naujaat. These findings agree with previous findings from Narciso-da459 Rocha et al. (2014) and Gaze et al. (2011) who observed that int1 is particularly prevalent in 460 wastewater. In addition, the sulfonamides (to which sul type genes confer resistance) group of 461 antibiotics is one of the most commonly found in wastewater (Davies \& Davies, 2010). More 462 recently, the mostly plasmid-borne qnrS have been documented to be prevalent in wastewater 463 sources, where it may be a concern for horizontal gene transfer events (Rodriguez-Moraz et al., 
2015). Although not shown in Figure 6, the gene mecA was present in the raw wastewater just slightly above the LOQ at $1.9 \log$ gene copies $/ \mathrm{mL} \pm 0.3$ S.D. and $2.0 \log$ gene copies $/ \mathrm{mL} \pm 0.2$ S.D. for Sanikiluaq and Naujaat, respectively. While, vanA was only observed above the LOQ once in one of the raw pump truck samples in Sanikiluaq.

Figure 7 shows the relative abundance of the distribution of ARGs in the raw wastewater were not significantly different between the two sites (paired t-test, $\mathrm{t}=0.96, \mathrm{df}=8, \mathrm{p}=0.36$ ). This could be attributed to similar strength and quality raw wastewater, and similar rates and types of 471 clinical use of the antibiotics within the two hamlets. An exception to this trend can be observed 472 with the qnrS gene target in Sanikiluaq, which was not present above LOQ in the raw 473 wastewater.

\subsection{Absolute abundance in wetlands}

Absolute abundance for each individual ARG target at the sample locations within the wetlands is illustrated in Figure 6. The ARGs ermB, tetO, bla $a_{T E M}$, and bla $a_{C T X-M}$ were all below the LOQ (but above the LOD only in the spring excluding the reference site) in the water samples collected from the mid-point, outlet and reference wetlands in Sanikiluaq. In contrast, ermB, tetO, bla $a_{T E M}$, and $b l a_{C T X-M}$ were all present within the wetland during the spring period in

480 Naujaat. At times there was limited log reduction in some ARGs as wastewater progressed 481 through the wetland in Naujaat. The persistence of ARGs in Naujaat can be explained by the 482 short HRT in the wetland in the spring, and lower dilution at this site compared to Sanikiluaq. At 483 both sites, the spring conditions in all instances produced the highest gene absolute abundances 484 within the wetlands. The ARG mecA and vanA was generally at or below the LOQ levels in soil and water at both sites, therefore the individual plots for this ARG were not presented. However, it should be noted 
mecA was detected in low concentrations of $2.9 \log$ gene copies per gram in the soil at the midpoint, and concentrations of $2.1 \log$ gene copies per $\mathrm{mL}$ in the effluent and reference wetland water in Naujaat. MecA and vanA are often present on mobile genetic elements in chromosomal DNA instead of plasmids (Biavasco et al., 2007; Colomer-Lluch et al., 2011) and therefore the 491 low prevalence in the study wetlands may be due to low persistence of the bacteria carrying these 492 genes.

493 Comparison of the findings between Sanikiluaq and Naujaat with the findings from Chaves494 Barquero et al. (2016) on the Cambridge Bay lagoon and WTA provides broader contextual 495 analysis of ARGs in wetland settings in Nunavut as shown in Table 2. In terms of the sul and tet 496 markers, the Cambridge Bay site had similar values to Naujaat in this study during the spring. In 497 terms of 16S rRNA markers, Cambridge Bay and Sanikiluaq were similar.

Table 2. Comparison of ARG absolute abundances in the wetland effluent from Cambridge Bay from Chaves- Barquero et al. (2016) and Sanikiluaq and Naujaat, Nunavut.

\begin{tabular}{llllll}
\hline \multirow{2}{*}{$\begin{array}{l}\text { Gene target } \\
(\log \text { gene copies } / \mathrm{mL})\end{array}$} & \multicolumn{5}{c}{ Site } \\
\cline { 2 - 6 } & Cambridge Bay $^{\mathrm{a}}$ & \multicolumn{5}{c}{ Sanikiluaq } & Naujaat & \\
\cline { 2 - 6 } Tetracycline resistance & 3.8 & 0.6 & -0.008 & 4.2 & 2.7 \\
Sulfonamide resistance & 5.6 & 2.9 & -0.1 & 5.3 & 3.6 \\
16S rRNA & 7.3 & 7.1 & 6.7 & 9.7 & 9
\end{tabular}

${ }^{a}$ Results from Barquero et al. (2016) study.

501 Figure 7 shows a decline in the relative abundance of ARGs which was generally observed from 502 the inlet to the outlet of the wetland in Sanikiluaq. In Naujaat, the relative abundances decreased 503 to a lesser extent within the wetland. Furthermore, during the summer there were increases of 504 relative abundance in Naujaat (0.2 and $1.3 \mathrm{log}$ gene copies per $16 \mathrm{~S}$ rRNA genes for int1, and 
$q n r S$, respectively), which indicated potential enrichment of these genes in the wetland during this period.

\subsection{Absolute abundance in soil}

The gene targets were also widely detected in the wetland soil samples (Figure 6). It should be noted that the soil samples were collected during the summer period. Although the water and soil

510 concentrations are not directly comparable $(\mathrm{CFU} / \mathrm{mL}$ vs $\mathrm{CFU} / \mathrm{g})$, the fact that the soil

511 concentrations were multiple orders of magnitude greater for some ARGs (e.g., sul1, sul2, tetO,

512 qnrS) may suggest that the soil acts as a sink, or that the soil provides a favourable biofilm

513 environment conducive to ARG carrying bacteria proliferation. Soil reservoirs for antibiotic

514 resistance and ancient antibiotic resistance elements residing in soil environments is a field of

515 current study and remains a field requiring further study to protect human health (Allen et al.,

516 2010). There were numerous instances whereby the gene absolute abundances were below the

517 LOD and LOQ in the soil samples (Figure 6). At both sites, none of the soil samples contained

518 levels of bla $a_{\text {СтX-M }}$ above the LOQ despite it being quantified in the Naujaat water samples from

519 the wetland. This may weakly infer that this ARG, commonly found among members of

520 Enterobacteriaceae (Narciso-da-Rocha et al., 2014), may not be associated with the bacterial

521 communities in the soil biofilms.

522 Figure 7 shows the relative abundance of the gene targets in soil which were generally much

523 lower than observed with the water samples. This would be expected given the greater microbial

524 biomass and genetic material in the soil samples compared to the water samples. 


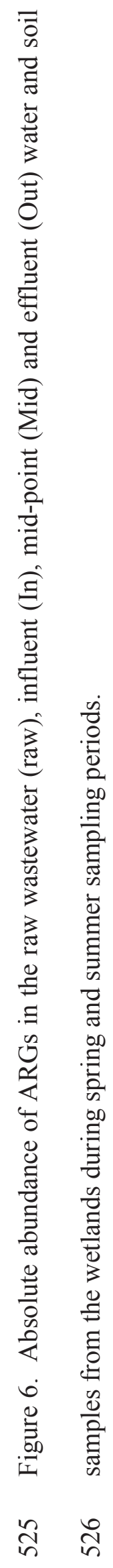




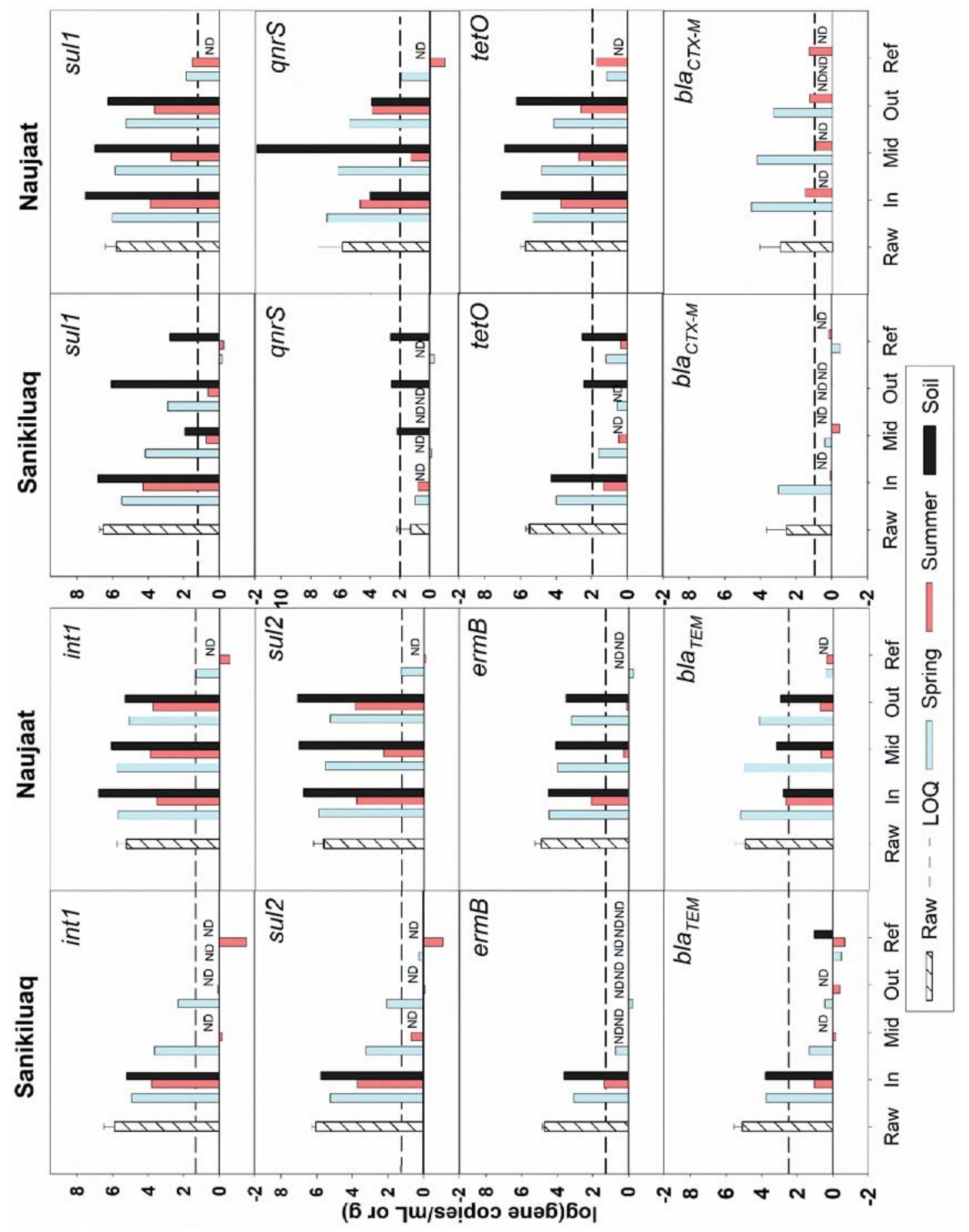




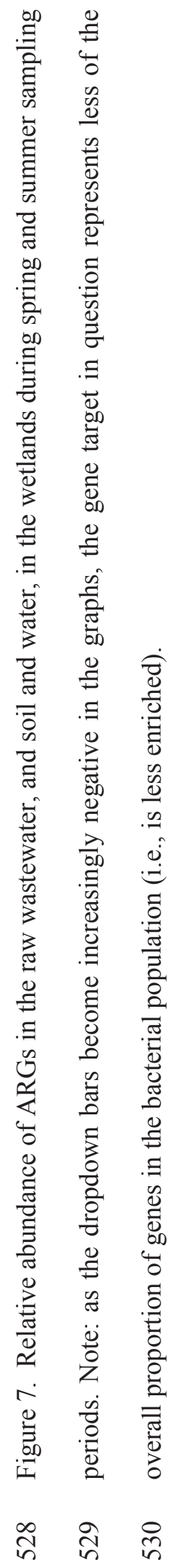




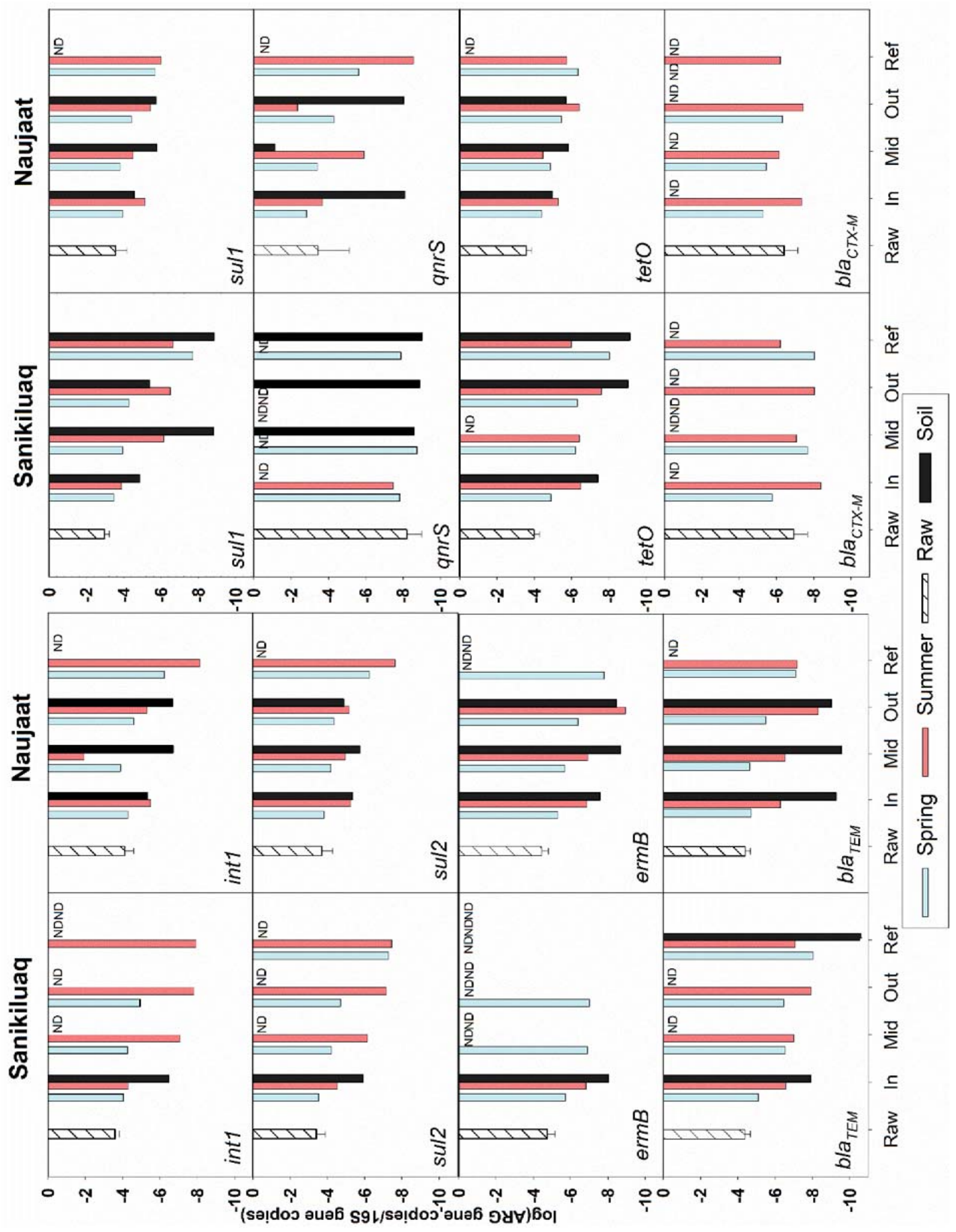


533 The absolute abundance of the gene targets in water were observed to be below the LOQ within

534 the reference wetlands, with the exception of int1, sul1, sul2, and bla $a_{C T X-M}$ in Naujaat; however the concentrations were close to the LOQ (Figure 6). These ARGs that were observed in the water of the reference wetland in Naujaat were also detected in much greater absolute abundances within both the raw wastewater and within the treatment wetland, which would suggest that there is selective pressure associated with the wastewater, which may contribute to the proliferation of naturally occurring ARGs. In three cases ARGs were detectable at low levels

540 in the soil of the reference wetlands, including sul1, qnrS, and tetO in Sanikiluaq, which may 541 also suggest these genes are naturally present in the soil, and potentially not originating from 542 anthropogenic sources at the reference sites. The reference wetlands generally had the lowest 543 relative abundance for all samples at both study sites (Figure 7).

544 Recent research has begun to assess the possibility of anthropogenic impacts on AMR in remote and seemingly un-impacted marine and terrestrial environments. Anthropogenic impacts on global ARG distribution was investigated in remote Arctic marine waters by Tan et al. (2017), 547 where the human mitochondrial gene target Hmt was found in remote high artic marine sediment 548 and correlated with elevated relative abundance of ARGs. Zhang et al. (2018) studied ARGs in 549 relatively un-impacted (glacial soil and permafrost) and anthropogenic environments (river 550 sediment), where it was observed that there was greater abundance and diversity in the 551 anthropogenic environment, than the relatively un-impacted sites. With the far-reaching global 552 spread of AMR, it is important to develop an understanding of the ancient resistome as baseline 553 for change monitoring and the reference sites in the tundra wetlands provide an example of a 554 relatively un-impacted environment. In addition, sites with naturally occurring ARGs could 
contribute to the proliferation of ARGs given influxes of nutrients and environmental changes over time from anthropogenic impacts.

\subsection{Correlations between ARGs and water quality indicators (WQI)}

The PCA results with the WQIs and gene targets is presented in Figure 8a and illustrates that the gene targets were positively correlated with each other. Some gene targets were excluded from the PCA due to low or inconsistent detection levels across the hamlets (mecA, vanA, qnrS, ermB, and $\left.b l a_{C T X-M}\right)$. Total coliform, E. coli, VSS, and Zinc were the other water quality parameters that were the most strongly correlated with the gene targets. This positive correlation between ARGs and total coliforms and E. coli is expected because the bacteria often carry the ARGs within their cellular structure in a selective environment, therefore a high number of bacteria and accordingly ARGs would be anticipated in wastewater streams. The correlation of ARGs with organic matter may also be related to elevated nutrients for the bacteria to consume and hence proliferate. The positive correlation of ARGs with zinc may be attributed to co-selection of ARGs and zinc which has been observed by Pal et al. (2015). Many of the other wastewater contaminants including $\mathrm{TN}, \mathrm{Cu}, \mathrm{TAN}, \mathrm{TP}, \mathrm{Al}, \mathrm{Fe}, \mathrm{TSS}, \mathrm{CBOD}_{5}$, and $\mathrm{Mn}$ had weak positive correlations with the gene targets which indicated that their persistence in the wetlands followed similar trends. Overall, the results of the PCA indicated that fecal indicators, such as E. coli, and organic matter (in the form of VSS) are possible indicators for elevated ARG levels downstream of municipal wastewater sources in tundra wetlands. Figure $8 \mathrm{~b}$ shows the PCA scores plot from which it can be qualitatively noted that there were seasonal differences in the gene targets and WQI results, with the spring and summer sample scores grouped separately. Differences in concentrations based on the distance from the wastewater source were also observed, with sample scores of similar qualities grouped together. 

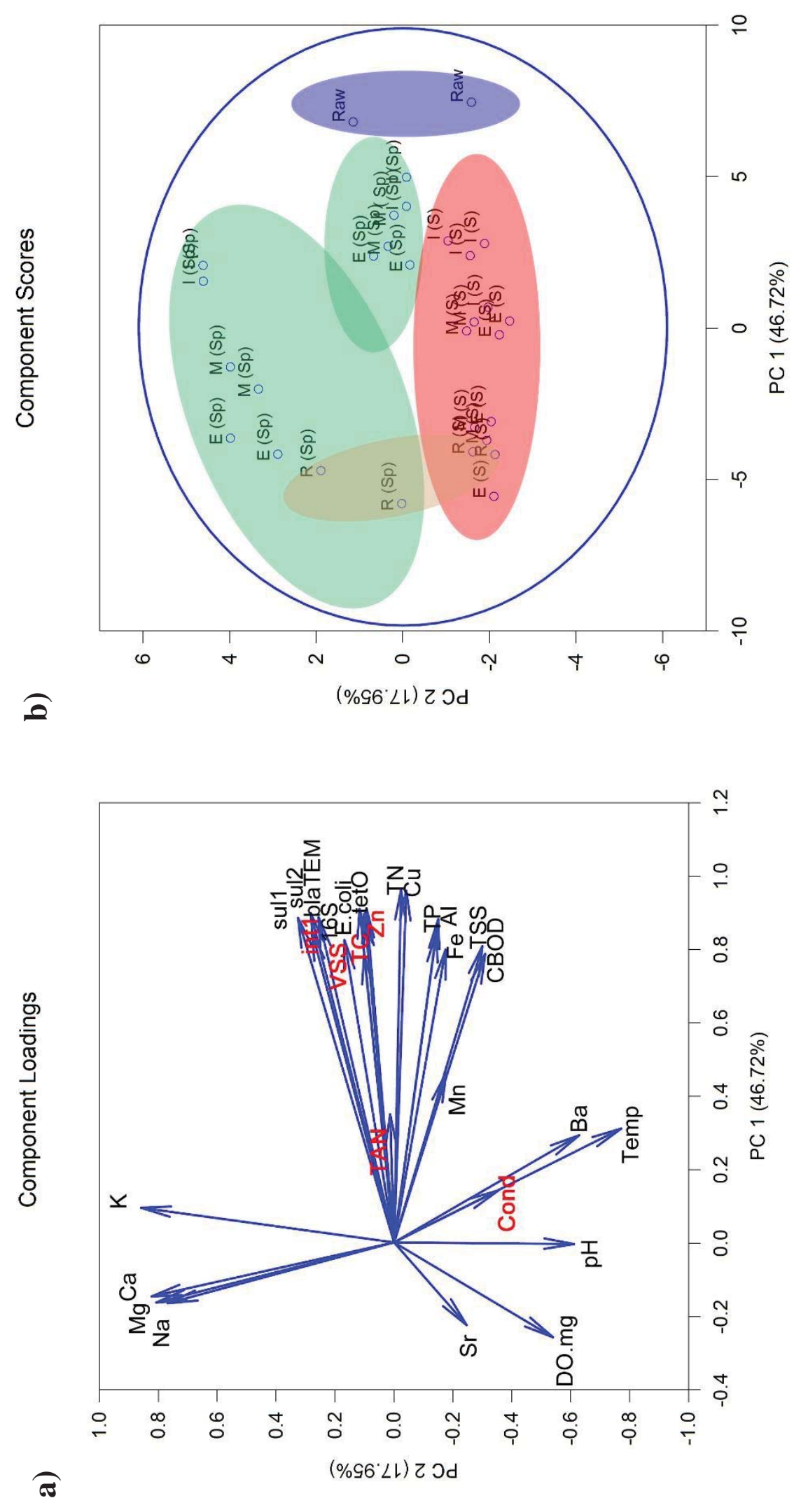

过

$2 \quad$

च

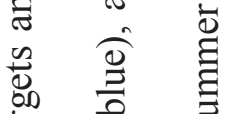

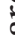

$\frac{\substack{0 \\ 0}}{0}$

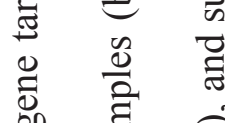

¿

廿

흘 胥 क

ठัँ

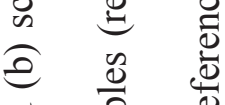

च 芯

苟它

ठี

䒠

$\stackrel{0}{\stackrel{0}{4}}$

कृ

.2

ब $\underbrace{0}_{0}$.

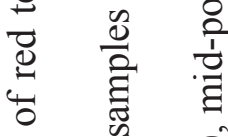

o $\quad \infty \quad \hat{\ominus}$

点 营

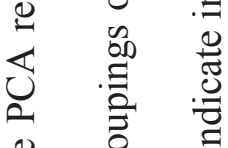

‡ के

फे

을

की

ग

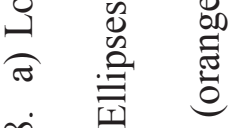

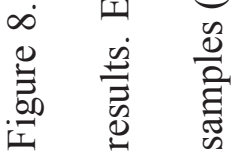

in i $\frac{\infty}{n}$ 


\subsection{First-order rate constants of ARGs}

583 The first-order rate constants determined for the gene targets in the wetlands are summarized in

584 Table 3. It should be noted that the $k_{20}$ 's for a few of the gene targets (including mecA and vanA)

585 were not determined (denoted by $\mathrm{n} / \mathrm{a}$ in Table 3), due to absolute abundances being below LOD

586 or below the LOQ within the wetlands or dilution from external hydrologic contributions.

587 Overall, the first-order rate constants determined for the gene targets fell within the $40^{\text {th }}$ to $95^{\text {th }}$ 588 percentile (ranging from $52 \mathrm{~m} / \mathrm{y}$ for sul1 to $1,549 \mathrm{~m} / \mathrm{y}$ for int1) for Sanikiluaq, and within the $50^{\text {th }}$ 589 to $95^{\text {th }}$ percentile (ranging from $81 \mathrm{~m} / \mathrm{y}$ for sul1 to $1,954 \mathrm{~m} / \mathrm{y}$ for $16 \mathrm{~S}$ rRNA) for Naujaat, 590 compared to fecal coliforms measured in a group of FWS constructed wetlands compiled by 591 Kadlec and Wallace (2009). The $k_{20}$ 's were variable and unique for each gene target. This is a preliminary attempt at the assessment of first-order rate constants for ARG and other gene targets in wetlands impacted by municipal wastewater and further study should be conducted, especially

594 due to the wide variability in $k_{20}$ 's, to assess whether these compare to other cold climate treatment wetlands. These first-order rate constants are important parameters to inform design of passive treatment wetlands for ARG specific removal, as they describe the rates at which the

597 wetlands attenuate the ARGs assessed and allow for sizing requirement calculations to inform 598 the design process.

599 Table 3. First-order rate constants $\left(k_{20}\right)$ for the absolute abundances of the gene targets and $E$.

600 coli in the wetlands.

\begin{tabular}{|c|c|c|c|c|c|c|c|c|c|c|c|}
\hline Site & & int1 & sul1 & sul2 & $q n r S$ & ermB & tetO & $\begin{array}{l}b_{M} l a_{T E} \\
\end{array}$ & $\begin{array}{l}\text { bla }_{C T} \\
X-M\end{array}$ & $\begin{array}{l}16 S \\
r R N \\
A\end{array}$ & $\begin{array}{l}\text { E. } \\
\text { coli }\end{array}$ \\
\hline Sanikiluaq & $k_{20}(\mathrm{~m} / \mathrm{y})$ & 1549 & 52 & 428 & $\mathrm{n} / \mathrm{a}^{\mathrm{b}}$ & $\mathrm{n} / \mathrm{a}$ & $\mathrm{n} / \mathrm{a}$ & $\mathrm{n} / \mathrm{a}$ & $\mathrm{n} / \mathrm{a}$ & $\mathrm{n} / \mathrm{a}$ & 1592 \\
\hline
\end{tabular}




\begin{tabular}{llllllllllll}
\hline & $\begin{array}{l}\text { Percentile } \\
(\%)\end{array}$ & 95 & 40 & 90 & $\mathrm{n} / \mathrm{a}$ & $\mathrm{n} / \mathrm{a}$ & $\mathrm{n} / \mathrm{a}$ & $\mathrm{n} / \mathrm{a}$ & $\mathrm{n} / \mathrm{a}$ & $\mathrm{n} / \mathrm{a}$ & 95 \\
Naujaat & $k_{20}(\mathrm{~m} / \mathrm{y})$ & & & & & & & & & & \\
& & 203 & 81 & 108 & 106 & 1117 & 254 & 157 & 473 & 1954 & 146 \\
& $\begin{array}{l}\text { Percentile } \\
(\%)\end{array}$ & 80 & 50 & 60 & 60 & 95 & 80 & 70 & 90 & 95 & 70 \\
& $(\%)$ & & & & & & & & & \\
\hline
\end{tabular}

601 a Percentiles were where the $k_{20}$ 's from this study fell in comparison to a distribution of $k_{20}$

602 values for fecal coliforms from $n=47$ wetland years for 23 wetlands FWS constructed wetlands

603 summarized by Kadlec and Wallace (2009). The $k_{20}$ 's from Kadlec and Wallace are based on

604 calculation using nominal HRT.

605 b The $k_{20}$ 's were not determined for ermB, tetO, bla $a_{T E M}$ and bla ${ }_{C T X-M}$ in Sanikiluaq because the 606 ARG concentrations within the wetland were below LOQ. The $k_{20}$ for 16S rRNA could not be 607 determined for Sanikiluaq due to dilution from external hydrologic contributions.

\section{4. Conclusions}

609 This study demonstrated that the measured suite of nine ARGs were elevated above reference

610 conditions at the wetland outlet at both sites, except for mecA and vanA. It was hypothesized that

611 the hydrology of the systems would play a large role in the concentrations and spatial

612 distribution of the ARGs within the wetlands, and this was supported by the data. Notably, the 613 relatively short HRTs ( $<2$ days) during the high flow periods of the spring freshet produced the 614 period with the highest ARG absolute abundance concentrations. This spring period can be 615 viewed as a worst case scenario for ARG exposure risk within tundra wetlands impacted by 616 municipal wastewater originating from continuous discharge systems. Overall, Sanikiluaq had 617 improved levels of ARGs in comparison to Naujaat which may also have been linked hydrology 618 and latitude differences. Elevated levels of ARGs in soil samples in comparison to the water 619 samples collected in the summer period illustrated that the soils could either retain ARGs from a 620 period of higher concentrations in the water, or may provide an environment conducive to 
proliferation of bacteria that may carry the ARGs. The preliminary first-order rate constants were widely variable within the wetlands ranging from $52 \mathrm{~m} / \mathrm{y}$ to $1,954 \mathrm{~m} / \mathrm{y}(\overline{\mathrm{x}}=587 \mathrm{~m} / \mathrm{y})$ depending on the specific gene target. This study has provided the first assessment of ARG concentrations in tundra wetlands over an entire treatment season, to our knowledge the first assessment of the kinetics of ARG removal in these unique wetland systems, and comparative characterization of ARGs in un-impacted tundra wetlands.

\section{Acknowledgments}

628 Funding for this study was provided by the Community and Government (CGS) Services 629 division of the Government of Nunavut and Natural Sciences and Engineering Research Council 630 (NSERC) Strategic Grant STPGP 463352 - 14. The authors would like to express gratitude to 631 the two anonymous reviewers for providing generous and detailed feedback to improve the 632 manuscript. The authors would also like to thank the field personnel which included: Dr. Colin 633 Ragush, Rob Johnson, Audrey Hiscock, and Kiley Daley. Thank you to Lindsay Johnston for 634 assistance with mapping. The authors would like to thank the Hamlets of Sanikiluaq and Naujaat 635 for their help and participation with the completion of the study. We would like to thank the 636 Hamlet offices and SAOs for their help arranging a bear monitor and the council meetings. 637 Specifically, we would like to extend our gratitude to our bear monitors Eva Arragutainaq and 638 Pierre Kipsigak who helped immensely to ensure site safety. We extend our thanks to William

639 Hodgson from the CGS in Sanikiluaq, and Megan Lusty (CGS regional engineer for the Kivalliq 640 region of the GN). 
643 American Public Health Association (APHA) (2012). Standard methods for the examination of 644 water and wastewater. 22 ed. Water Environment Federation. Washington District of 645 Columbia, United States. Pp. 1496.

646 Alberta Environment (2000). Guidelines for the approval and design of natural and constructed 647 treatment wetlands for water quality. Municipal Program Development Branch. Environmental Sciences Division. Edmonton, Alberta, Canada. Pp. 127. Retrieved from: http://aep.alberta.ca/water/legislationguidelines/documents/WetlandsWaterQualityImprovement-Mar2000.pdf $\quad$ [January $\quad 31$, $2018]$.

Allen, H. K., Donato, J., Wang, H. H., Cloud-Hansen, K. A., Davies, J., \& Handelsman, J. (2010). Call of the wild: antibiotic resistance genes in natural environments. Nature Reviews

Ashbolt, N. J., Amézquita, A., Backhaus, T., Borriello, P., Brandt, K. K., Collignon, P., Coors, A., Finley, R., Gaze, W., Heberer, T., Lawrence, J.R., Larsson, D.G.,J., McEwen, S.A., Ryan, J.J., Schönfeld, J., Silley, P., Snape, J.R., Van den Eede, C., \& Topp, E. (2013). Human health risk assessment (HHRA) for environmental development and transfer of antibiotic resistance. Environmental Health Perspectives (Online), 121(9), 993. doi:10.1289/ehp.1206316 
is associated with urban environments. Infection ecology \& epidemiology, 6(1), 32334. doi: 10.3402/iee.v6.32334

Balch, G., Hayward, J., Jamieson, R., Wootton, B., \& Yates, C. N. (2018). Recommendations for the Use of Tundra Wetlands for Treatment of Municipal Wastewater in Canada's Far North. In Multifunctional Wetlands (Pp. 83-120). Nagabhatla, N. \& Metcalfe, C. (Eds.) Springer Nature. Pp. 308.

Barraud, O., Baclet, M. C., Denis, F., \& Ploy, M. C. (2010). Quantitative multiplex real-time PCR for detecting class 1, 2 and 3 integrons. Journal of antimicrobial chemotherapy, 65(8), 1642-1645. doi: 10.1093/jac/dkq167

Biavasco, F., Foglia, G., Paoletti, C., Zandri, G., Magi, G., Guaglianone, E., Sundsfjord, A., Pruzzo, C., Donelli, G., \& Facinelli, B. (2007). VanA-type enterococci from humans, animals, and food: species distribution, population structure, Tn1546 typing and location, and virulence determinants. Applied and environmental microbiology, 73(10), 3307-3319. doi: 10.1128/AEM.02239-06

Böckelmann, U., Dörries, H. H., Ayuso-Gabella, M. N., de Marçay, M. S., Tandoi, V., Levantesi, C., Masciopinto, C., Van Houtte, E., Szewzyk, U., Wintgens, T., \& Grohmann, E. (2009). Quantitative PCR monitoring of antibiotic resistance genes and bacterial pathogens in three European artificial groundwater recharge systems. Applied and environmental microbiology, 75(1), 154-163. doi: 10.1128/AEM.01649-08

Bouki, C., Venieri, D., \& Diamadopoulos, E. (2013). Detection and fate of antibiotic resistant bacteria in wastewater treatment plants: a review. Ecotoxicology and environmental safety, 91, 1-9. doi: 10.1016/j.ecoenv.2013.01.016 
Boutilier, L., Jamieson, R., Gordon, R., Lake, C., \& Hart, W. (2009). Adsorption, sedimentation, and inactivation of E. coli within wastewater treatment wetlands. Water Research, 43(17), 4370-4380. doi: 10.1016/j.watres.2009.06.039

Chapra, S.C., (1997). Surface water-quality modeling, vol. 1. McGraw-Hill, New York, United States. Pp. 844.

Chaves-Barquero, L. G., Luong, K. H., Mundy, C. J., Knapp, C. W., Hanson, M. L., \& Wong, C. S. (2016). The release of wastewater contaminants in the Arctic: A case study from Cambridge Bay, Nunavut, Canada. Environmental Pollution, 218, 542-550. doi: 10.1016/j.envpol.2016.07.036

Colomer-Lluch, M., Jofre, J., \& Muniesa, M. (2014). Quinolone resistance genes (qnrA and qnrS) in bacteriophage particles from wastewater samples and the effect of inducing agents on packaged antibiotic resistance genes. Journal of Antimicrobial Chemotherapy, 69(5), 1265-1274. doi: 10.1093/jac/dkt528

Colomer-Lluch, M., Jofre, J., \& Muniesa, M. (2011). Antibiotic resistance genes in the bacteriophage DNA fraction of environmental samples. PloS one,6(3), e17549. doi: 10.1371/journal.pone.0017549

CWRS (Centre for Water Resources Studies) (2016). Guidelines for the Design and Assessment of Tundra Wetland Treatment Areas in Nunavut. Technical report prepared for Community and Government Services department of the Government of Nunavut. Halifax, Nova Scotia. Pp. 64. Retrieved from: http://centreforwaterresourcesstudies.dal.ca/files/documents/Report\%20CWRS\%20wetland \%20design\%20guidelines.pdf [January 30, 2018]. 
Czekalski, N., Berthold, T., Caucci, S., Egli, A., \& Bürgmann, H. (2012). Increased levels of multiresistant bacteria and resistance genes after wastewater treatment and their dissemination into Lake Geneva, Switzerland. Frontiers in Microbiology, 3, 106. doi: 10.3389/fmicb.2012.00106.

D’Costa, V. M., King, C. E., Kalan, L., Morar, M., Sung, W. W., Schwarz, C., Froese, D., Zazula, G., Calmels, F., Debruyne, R., Golding, B.G., Poinar, H.N., \& Wright, G.D. (2011). Antibiotic resistance is ancient. Nature, 477(7365), 457-461. doi: 10.1038/nature10388

Daley, K., Castleden, H., Jamieson, R., Furgal, C., \& Ell, L. (2015). Water systems, sanitation, and public health risks in remote communities: Inuit resident perspectives from the Canadian Arctic. Social Science \& Medicine, 135, 124-132. doi: 10.1016/j.socscimed.2015.04.017

Daley, K., Castleden, H., Jamieson, R., Furgal, C., \& Ell, L. (2014). Municipal water quantities and health in Nunavut households: an exploratory case study in Coral Harbour, Nunavut, Canada. International journal of circumpolar health,73(1), 23843. doi: 10.3402/ijch.v73.23843

Davies, J., \& Davies, D. (2010). Origins and evolution of antibiotic resistance. Microbiology and molecular biology reviews, 74(3), 417-433. doi: 10.1128/MMBR.00016-10

Dingman, S. L. (2002). Physical Hydrology. Second edition. Waveland Press Inc. Long Grove, Illinois, United States. Pp. 642.

Forsberg, K. J., Reyes, A., Wang, B., Selleck, E. M., Sommer, M. O., \& Dantas, G. (2012). The shared antibiotic resistome of soil bacteria and human pathogens. Science, 337(6098), $1107-$ 1111. doi: $10.1126 /$ science. 1220761 
Founou, L. L., Founou, R. C., \& Essack, S. Y. (2016). Antibiotic resistance in the food chain: a developing country-perspective. Frontiers in microbiology, 7, 1881. doi: 10.3389/fmicb.2106.01881

Francois, P., Pittet, D., Bento, M., Pepey, B., Vaudaux, P., Lew, D., \& Schrenzel, J. (2003). Rapid detection of methicillin-resistant Staphylococcus aureus directly from sterile or nonsterile clinical samples by a new molecular assay. Journal of Clinical Microbiology, 41(1), 254-260. doi: 10.1128/JCM.41.1.254-260.2003

Gaze, W. H., Zhang, L., Abdouslam, N. A., Hawkey, P. M., Calvo-Bado, L., Royle, J., Brown, H., Davis, S., Kay, P., Alistair, B., \& Wellington, E. M. (2011). Impacts of anthropogenic activity on the ecology of class 1 integrons and integron-associated genes in the environment. The ISME journal, 5(8), 1253. doi: 10.1038/ismej.2011.15

Gillings, M. R., Gaze, W. H., Pruden, A., Smalla, K., Tiedje, J. M., \& Zhu, Y. G. (2015). Using the class 1 integron-integrase gene as a proxy for anthropogenic pollution. The ISME journal, 9(6), 1269. doi: 10.1038/ismej.2014.226

Government of Canada (2016a). Kuujuarapik A, Quebec. Canadian Climate Normals 1981-2010 Station Data. Retrieved from: http://climate.weather.gc.ca/climate normals/index_e.html?\#1981 [January 31, 2018].

Government of Canada (2016b). Repulse Bay A, Nunavut. Canadian Climate Normals 19812010 Station Data. Retrieved from: http://climate.weather.gc.ca/climate_normals/index_e.html?\#1981 [January 31, 2018].

Government of Canada (2016c). Canadian antimicrobial resistance surveillance system - report 2016. Public Health Agency of Canada. Ottawa, Ontario. Retrieved from: 
https://www.canada.ca/en/public-health/services/publications/drugs-healthproducts/canadian-antimicrobial-resistance-surveillance-system-report-2016.html\#a4-4-1 [April 25, 2018].

Government of Canada (2017). Geospatial data extraction. Natural Resources Canada. Retrieved from: http://maps.canada.ca/czs/index-en.html [January 31, 2018].

Government of Québec (2014). CENTRE D'EXPERTISE EN ANALYSE ENVIRONNEMENTALE DU QUÉBEC. Détermination des métaux : méthode par spectrométrie de masse à source ionisante au plasma d'argon. MA. 200 - Mét 1.2, Rév. 5, Ministère du Développement durable, de l'Environnement et de la Lutte contre les changements climatiques du Québec, 2014, 36 pp. Retrieved from: http://www.ceaeq.gouv.qc.ca/methodes/pdf/MA200Met12.pdf [May 3, 2018].

Gunnarsdóttir, R., Jenssen, P. D., Jensen, P. E., Villumsen, A., \& Kallenborn, R. (2013). A review of wastewater handling in the Arctic with special reference to pharmaceuticals and personal care products (PPCPs) and microbial pollution. Ecological engineering, 50, 76-85. doi: 10.1016/j.ecoleng.2012.04.025

Hamlet of Repulse Bay. (2015). Annual Report for the Hamlet of Repulse Bay. Repulse Bay, Nunavut. Retrieved from: http://www.nwboen.ca/public/registry/3\%20MUNICIPAL/3B/3BM\%20-\%20Municipality/3BMREP1520/3\%20TECH/1\%20GENERAL\%20(B)/ [January 31, 2018].

Hamlet of Sanikiluaq. (2015). Annual Report for the Hamlet of Sanikiluaq. Sanikiluaq, Nunavut. Retrieved from: http://www.nwb-oen.ca/public/registry/3\%20MUNICIPAL/3B/3BM\%20- 

2018].

Harper, S. L., Edge, V. L., Ford, J., Thomas, M. K., Pearl, D. L., Shirley, J., \& McEwen, S. A. (2015). Acute gastrointestinal illness in two Inuit communities: burden of illness in Rigolet and Iqaluit, Canada. Epidemiology \& Infection, 143(14), 3048-3063. doi: $10.1017 / \mathrm{S} 0950268814003744$

Harper, S. L., Edge, V. L., Schuster-Wallace, C. J., Berke, O., \& McEwen, S. A. (2011). Weather, water quality and infectious gastrointestinal illness in two Inuit communities in Nunatsiavut, Canada: potential implications for climate change. EcoHealth, 8(1), 93-108. doi: 10.1007/s10393-011-0690-1

Hayward, J., \& Jamieson, R. (2015). Derivation of treatment rate constants for an arctic tundra wetland receiving primary treated municipal wastewater. Ecological Engineering, 82, 165 174. doi: 10.1016/j.ecoleng.2015.04.086

Hayward, J., Jamieson, R., Boutilier, L., Goulden, T., \& Lam, B. (2014). Treatment performance assessment and hydrological characterization of an arctic tundra wetland receiving primary treated municipal wastewater. Ecological engineering, 73, 786-797. doi: 10.1016/j.ecoleng.2014.09.107

Hayward, J. (2013). Treatment performance assessment and modeling of a natural tundra wetland receiving municipal wastewater. Master of Applied Science dissertation. Dalhousie University, Halifax, Nova Scotia, Canada. Pp. 173. Retrieved from: file://C:/Users/jenny/Downloads/Hayward-Jennifer-MASc-ENVENG-August-2013.pdf [April 25, 2018]. 
794 Heuer, H., Focks, A., Lamshöft, M., Smalla, K., Matthies, M., \& Spiteller, M. (2008). Fate of

795 sulfadiazine administered to pigs and its quantitative effect on the dynamics of bacterial

796 resistance genes in manure and manured soil. Soil Biology and Biochemistry, 40(7), 1892-1900.

797 doi: 10.1016/j.soilbio.2008.03.014

798 Howell, J. M., Coyne, M. S., \& Cornelius, P. L. (1996). Effect of sediment particle size and 799 temperature on fecal bacteria mortality rates and the fecal coliform/fecal streptococci

$800 \quad$ ratio. Journal of Environmental Quality, 25(6), 1216-1220. doi:

$801 \quad 10.2134 /$ jeq1996.00472425002500060007x

802 Huang, Y., Hansen, L. T., Ragush, C. M., \& Jamieson, R. C. (2017). Disinfection and removal of 803

804 human pathogenic bacteria in arctic waste stabilization ponds. Environmental Science and Pollution Research, 1-13. doi: 10.1007/S11356-017-8816-9

Huijbers, P. M., Blaak, H., de Jong, M. C., Graat, E. A., Vandenbroucke-Grauls, C. M., \& de Roda Husman, A. M. (2015). Role of the environment in the transmission of antimicrobial

Johnson, K. (2008). A brief history of the past 60 years of Northern water and waste. Published 809 resistance to humans: a review. Environmental science \& technology, 49(20), 11993-12004. in the proceedings of the Annual Conference of Western Canada Water and Waste systems in the Far North. Conference proceeding paper from the Western Canada Water Conference \& Exhibition. September 23-26, 2014. Regina, Saskatchewan, Canada. Pp. 280. 

2018].

Kadlec, R. H., \& Wallace, S. (2009). Treatment wetlands. Second edition. CRC press. Boca Raton, Florida, United States. Pp. 1020.

Kadlec, R.H., \& Knight, R.L. (1996). Treatment wetlands. First edition. CRC Press. Boca Raton, Florida, United States. Pp. 893.

Knapp, C. W., Dolfing, J., Ehlert, P. A., \& Graham, D. W. (2009). Evidence of increasing antibiotic resistance gene abundances in archived soils since 1940. Environmental science \& technology, 44(2), 580-587.

Lachmayr, K. L., Kerkhof, L. J., DiRienzo, A. G., Cavanaugh, C. M., \& Ford, T. E. (2009). Quantifying nonspecific TEM $\beta$-lactamase (blaTEM) genes in a wastewater stream. Applied and environmental microbiology, 75(1), 203-211. doi: 10.1128/AEM.01254-08

Laxminarayan, R., Duse, A., Wattal, C., Zaidi, A. K., Wertheim, H. F., Sumpradit, N., Vlieghe, E., Hara, G.L., Gould, I.M., Goosens, H., Greko, C., So, A.D., Bigdeli, M., Tomson, G., Woodhouse, W., Ombaka, E., Peralta, A.Q., Qamar, F.N., Mir, F., Kariuki, S., Bhutta, Z.A., Coates, A., Bergstrom, R., Wright, G., Brown, E.D., Cars, O. (2013). Antibiotic resistance - the need for global solutions. The Lancet infectious diseases, 13(12), 10571098. doi: 10.1016/S1473-3099(13)70318-9

Martínez, J. L. (2008). Antibiotics and antibiotic resistance genes in natural environments. Science, 321(5887), 365-367. doi: 10.1126/science.1159483 
McConnell, M., (2017). Abundance of antibiotic resistance genes in two municipal wastewater treatment plants and receiving water in Atlantic Canada. Master of Applied Science Thesis dissertation. Dalhousie University, Halifax, Nova Scotia, Canada. Pp. 171. Retrieved from: http://dalspace.library.dal.ca/handle/10222/72949 [January 31, 2018].

Nagulapally, S. R., Ahmad, A., Henry, A., Marchin, G. L., Zurek, L., \& Bhandari, A. (2009). Occurrence of ciprofloxacin-, trimethoprim-sulfamethoxazole-, and vancomycin-resistant bacteria in a municipal wastewater treatment plant. Water Environment Research, 81(1), 8290. doi: $10.2175 / 106143008 \times 304596$

Narciso-da-Rocha, C., Varela, A. R., Schwartz, T., Nunes, O. C., \& Manaia, C. M. (2014). bla TEM and vanA as indicator genes of antibiotic resistance contamination in a hospital-urban wastewater treatment plant system. Journal of global antimicrobial resistance, 2(4), 309315. doi: 10.1016/j.jgar.2014.10.001

Neudorf, K. D., Huang, Y. N., Ragush, C. M., Yost, C. K., Jamieson, R. C., \& Hansen, L. T. (2017). Antibiotic resistance genes in municipal wastewater treatment systems and receiving waters in Arctic Canada. Science of the Total Environment, 598, 1085-1094. doi: 10.1016/j.scitotenv.2017.04.151

Nunavut Water Board (2015a). NWB Renewal Licence No. 3BM-SAN1520. Sanikiluaq, $\begin{array}{llll}\text { Nunavut. } & \text { Pp. } & \text { 29. } & \text { Retrieved }\end{array}$ oen.ca/registry/3\%20MUNICIPAL/3B/3BM\%20-\%20Municipality/3BM$\underline{\text { SAN1520/4\%20LICENCE/1\%20LICENCE/150514\%203BM- }}$ SAN1520\%20Renewal\%20Licence-OSAE.pdf [April 26, 2018]. 
Nunavut Water Board (2015b). NWB Renewal Licence No. 3BM-REP1520. Naujaat, Nunavut. Pp. 35. Retrieved from: ftp://ftp.nwb-oen.ca/registry/3\%20MUNICIPAL/3B/3BM $\% 20$ \%20Municipality/3BM-REP1520/4\%20LICENCE/1\%20LICENCE/150409\%203BMREP1520\%20Renewal\%20Water\%20Licence-\%20OBME.pdf [April 26, 2018].

Pal, C., Bengtsson-Palme, J., Kristiansson, E., \& Larsson, D. J. (2015). Co-occurrence of resistance genes to antibiotics, biocides and metals reveals novel insights into their coselection potential. BMC genomics, 16(1), 964. doi: 10.1186/s12864-015-2153-5

Pardhan-Ali, A., Wilson, J., Edge, V. L., Furgal, C., Reid-Smith, R., Santos, M., \& McEwen, S. A. (2013). Community-level risk factors for notifiable gastrointestinal illness in the Northwest Territories, Canada, 1991-2008. BMC Public Health, 13(1), 63.

Qiu, Z., Yu, Y., Chen, Z., Jin, M., Yang, D., Zhao, Z., Wang, J., Shen, Z., Wang, X., Qian, D., Huang, A., Zhang, B., \& Li, J.-W. (2012). Nanoalumina promotes the horizontal transfer of multiresistance genes mediated by plasmids across genera. Proceedings of the National Academy of Sciences, 109(13), 4944-4949. doi: 10.1073/pnas.1107254109

Ragush, C. M., Schmidt, J. J., Krkosek, W. H., Gagnon, G. A., Truelstrup-Hansen, L., \& Jamieson, R. C. (2015). Performance of municipal waste stabilization ponds in the Canadian Arctic. Ecological Engineering, 83, 413-421. doi: 10.1016/j.ecoleng.2015.07.008

Ramey, A. M., Hernandez, J., Tyrlöv, V., Uher-Koch, B. D., Schmutz, J. A., Atterby, C., Järhult, J.D., \& Bonnedahl, J. (2017). Antibiotic-Resistant Escherichia coli in Migratory Birds Inhabiting Remote Alaska. EcoHealth, 1-10. doi: 10.1007/s10393-017-1302-5

Rizzo, L., Manaia, C., Merlin, C., Schwartz, T., Dagot, C., Ploy, M. C., Michael, I., \& FattaKassinos, D. (2013). Urban wastewater treatment plants as hotspots for antibiotic resistant 
bacteria and genes spread into the environment: a review. Science of the total environment, 447, 345-360. doi: 10.1016/j.scitotenv.2013.01.032

Rodriguez-Mozaz, S., Chamorro, S., Marti, E., Huerta, B., Gros, M., Sànchez-Melsió, A., Borrego, C., Barceló, D., \& Balcázar, J. L. (2015). Occurrence of antibiotics and antibiotic resistance genes in hospital and urban wastewaters and their impact on the receiving river. Water research, 69, 234-242. doi: 10.1016/j.watres.2014.11.021

Statistics Canada (2017a). Sanikiluaq, HAM [Census subdivision], Nunavut and Nunavut [Territory] (table). Census Profile. 2016 Census. Statistics Canada Catalogue no. 98-316X2016001. Ottawa, Ontario, Canada. Released November 29, 2017. Retrieved from: http://www12.statcan.gc.ca/census-recensement/2016/dp-pd/prof/index.cfm?Lang=E [January 31, 2018].

Statistics Canada (2017b). Naujaat, HAM [Census subdivision], Nunavut and Nunavut [Territory] (table). Census Profile. 2016 Census. Statistics Canada Catalogue no. 98-316X2016001. Ottawa, Ontario, Canada. Released November 29, 2017. Retrieved from: http://www12.statcan.gc.ca/census-recensement/2016/dp-pd/prof/index.cfm?Lang=E [January 31,2018$]$.

Suzuki, M. T., Taylor, L. T., \& DeLong, E. F. (2000). Quantitative analysis of small-subunit rRNA genes in mixed microbial populations via 5'-nuclease assays. Applied and environmental microbiology, 66(11), 4605-4614. doi: 10.1128/AEM.66.11.4605-4614.2000

Szczepanowski, R., Linke, B., Krahn, I., Gartemann, K. H., Guetzkow, T., Eichler, W., Pühler, A., \& Schlueter, A. (2009). Detection of 140 clinically relevant antibiotic-resistance genes in the plasmid metagenome of wastewater treatment plant bacteria showing reduced 
902

903

904

905

906

907

908

909

910

911

912

913

914

915

916

917

918

919

920

921

922

923

susceptibility to selected antibiotics. Microbiology, 155(7),

2306-2319. doi:10.1099/mic.0.028233-0

Tan, L., Li, L., Ashbolt, N., Wang, X., Cui, Y., Zhu, X., Xu, Y., Yang, Y., Mao, D. \& Luo, Y. (2017). Arctic antibiotic resistance gene contamination, a result of anthropogenic activities and natural origin. Science of The Total Environment. 621: 1176-1184. doi: 10.1016/j.scitotenv.2017.10.110

Taylor, N. G., Verner-Jeffreys, D. W., \& Baker-Austin, C. (2011). Aquatic systems: maintaining, mixing and mobilising antimicrobial resistance?. Trends in ecology \& evolution, 26(6), 278284. doi: 10.1016/j.tree.2011.03.004

USEPA (United Stated Environmental Protection Agency) (1994). Method 200.8, Revision 5.4: Determination of trace elements in waters and wastes by inductively coupled plasma - mass spectrometry. Environmental monitoring systems laboratory. Office of research and development. Cincinnati, Ohio. Pp. 58. Retrieved from: https://www.epa.gov/sites/production/files/2015-08/documents/method_200-8_rev_54 1994.pdf [May 3, 2018].

USEPA (United Stated Environmental Protection Agency) (1998). Method 6020A Inductively coupled plasma - mass spectrometry. Revision 1. Pp. 23. Retrieved from: https://www.epa.gov/sites/production/files/2015-07/documents/epa-6020a.pdf $\quad[$ May 3, 2018].

Volkmann, H., Schwartz, T., Bischoff, P., Kirchen, S., \& Obst, U. (2004). Detection of clinically relevant antibiotic-resistance genes in municipal wastewater using real-time PCR (TaqMan). Journal of microbiological methods, 56(2),

277-286. 
925 Water Environment Federation (2010). Natural Systems for Wastewater Treatment, third ed. WEF Manual of Practice No. FD-16. Alexandria, Virginia, United States. Pp. 508.

927 Yates, C. N., Wootton, B. C., \& Murphy, S. D. (2012). Performance assessment of arctic tundra municipal wastewater treatment wetlands through an arctic summer. Ecological engineering, 44, 160-173. doi: 10.1016/j.ecoleng.2012.04.011

930 Zhang, S., Yang, G., Hou, S., Zhang, T., Li, Z., \& Liang, F. (2018). Distribution of ARGs and 931 MGEs among glacial soil, permafrost, and sediment using metagenomic analysis. Environmental Pollution, 234, 339-346. doi: 10.1016/j.envpol.2017.11.031

933 